THERMAL BARR IER COATING ON HIGH TEMPERATURE

芵 INDUSTRIAL GAS TURB INE ENGINES

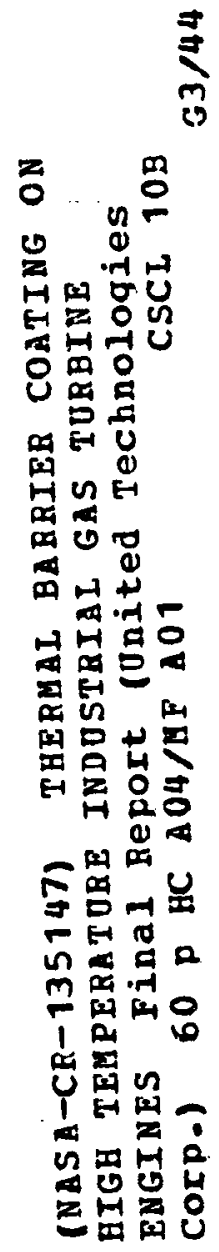

\author{
Nils Carlson \\ United Technologies Corporation \\ Power Systems Division \\ South Windsor, Connecticut 06074 \\ and \\ Barry L. Stoner \\ United Technologies Corporation \\ Pratt \& Whitney Aircraft \\ East Hartford, Connecticut 06108
}

\title{
February 1977
}

Prepared for. the

National Aeronautics and Space Administration

Lewis Research Center

Cleveland, Ohio 44135

Contract NAS3-20067

and the

ENERGY RESEARCH AND DEVELOPMENT ADMINISTRATION

Division of Conservation Research and Technology 


\begin{tabular}{|c|c|}
\hline $\begin{array}{l}\text { 1. Report No. } \\
\text { NASA CR-135147 }\end{array}$ & 3. Rucipient's Catalog No. \\
\hline \multirow{2}{*}{$\begin{array}{l}\text { 4. Title and SUbtitle } \\
\text { THERMAL BARRIER COATING ON HIGH TEMPERATURE } \\
\text { INDUSTRIAL GAS TURBINE ENGINES }\end{array}$} & $\begin{array}{l}\text { 5. Report Date } \\
\text { February } 1977\end{array}$ \\
\hline & 6. Performuny Organization Corde \\
\hline \multirow{2}{*}{$\begin{array}{l}\text { 7. Author(s) } \\
\text { Nils Carlson, Power Systems Division, and Barry L. Stoner, } \\
\text { Pratt \& Whitney Aircraft, both of United Technologies Corp. }\end{array}$} & $\begin{array}{l}\text { 8. Performing Organization Report No. } \\
\text { RSD-R-109 }\end{array}$ \\
\hline & \multirow[t]{2}{*}{ 10. Wark Unit No } \\
\hline 9. Performing Organization Name and Address. & \\
\hline \multirow{2}{*}{$\begin{array}{l}\text { United. Technologies Corporation } \\
\text { Rower Systems Division } \\
\text { South Windsor, Connecticut } 06074\end{array}$} & $\begin{array}{l}\text { 11. Contract or Grant No. } \\
\text { NAS3-20067 }\end{array}$ \\
\hline & 13. Type of Report and Period Covered \\
\hline \multirow{2}{*}{$\begin{array}{l}\text { 12. Sponsoring Agency Name and Address } \\
\text { Energy Research and Development Administration } \\
\text { Division of Conservation Research and Technology } \\
\text { Washington, D.C. } 20545\end{array}$} & Contractor Report \\
\hline & $\begin{array}{l}\text { 14. Sponsoring Agency } \\
\text { ERDA/NASA 0067/77/1 }\end{array}$ \\
\hline
\end{tabular}

15. Supplementary Notes

Final report. Prepared under Interagency Agreement E'(49-28)-1022. Project Manager, John S. Clark, Power Generation and Storage Division, NASA Lewis Research Center, Cleveland, Ohio 44135

16. Abstract

This study program identified significant benefits from applying thermal barrier coatings to hot section components of high temperature industrial gas turbine engines. The thermal barrier coating used in this study was a yttria stabilized zirconia material with a NiCrAlY undercoat, and the base engine used to establish improvements was the P\&WA FT50A-4 industrial gas turbine engine. The design benefits of thermal barrier coatings include simplified cooling schemes and the use of conventional alloys in the engine hot section. Cooling flow reductions and improved heating rates.achieved.with thermal barrier coating result in improved performance.

Economic benefits include reduced power production costs and reduced fuel consumption. Over the 30,000 hour life of the thermal barrier coated parts, fuel savings equivalent to $\$ 5$ million are projected and specific power (megawatts/mass of engine alrilow) improvements on the order of $13 \%$ are estimated. A research and evaluation program to develop thermal barrier coating technology is recommended. The program plan culminates in an industrail gas turbine engine demonstration of the potential benefits of thermal barrier coatings.

\begin{tabular}{|c|c|c|c|}
\hline $\begin{array}{l}\text { 17. Key Words (Suggested by Author(s)) } \\
\text { Thermal barrier coating; Industrial gas } \\
\text { turbine; Power cost benefits; Fuel } \\
\text { consumption; Durabllity development } \\
\text { plan; Ceramlc; Electric power }\end{array}$ & \multicolumn{3}{|c|}{$\begin{array}{l}\text { 18. Distribution Stutement } \\
\text { Unclassified - unlimited } \\
\text { STAR Category } 44\end{array}$} \\
\hline $\begin{array}{l}\text { 19. Security Classif. (of this report) } \\
\text { Unclassified }\end{array}$ & $\begin{array}{l}\text { If this pegs } \\
\text { solfied }\end{array}$ & $\begin{array}{c}\text { 21. No. of Pages } \\
55\end{array}$ & 22. Price \\
\hline
\end{tabular}

- For sale by the National Technical Information Service. Springlıeld. Vireııria 22161 
TABLE OF CONTENTS

2.0 HEAT TRANSFLR AND LIFE ANALYSIS

2.1 Combustor Analysis .

2.1.1 Base Combustor

2.1.2 Thermal Barrier Coated Combustor

2.2 Turbine Analysis

2.2.1 First Vanc Analysis With Thermal Barrier Coating

2.2.2 First-Stuge Blade and Second-Stage Airfoil Analysis

INTROUUCTION

1.2 Program

1.3 FT50 Engine Description

3.1 Performance Summary

3.2 Uncoated Performance

3.2.1 Base Engine Simple Cycle

3.2.2 Base Engine Combined Cycle

3.3 Thermal Barrier Coated Performance

3.3.1 Thermal Barrier Coating Simple Cycle

3.3.2 Thermal Barrier Coated Combined Cycle

4.2 Operating Cost Assumptions

4.3 Discussion Of Results

5.2 Phase II -- Coating Technology Development 46

5.2.1 Coating Process Technology 46

5.2.2 Coating Durability Teshnology 48

5.2.3 Coating Frosion-Corrosion Technology 48

5.3 Phase III - Design Support Technology 50

5.3.1 Material Design Properties 50

5.3.2 Design Tools Development $\quad 52$

5.4 Phase IV - Engine Programs 52 


\section{LIST OF ILLUSTRATION}

Figur:

Titlo

Page No.

1-1 Cross-Section of the Fr50 Engine

2-1 Basc Engine Design

2-2 Thermal Barrier Coated Design

2-3 Heat Transfer Coefficient Requirements for Transition Duct

2-4 FT50 First Stage Turbine-Kane

2-5 First Vane Cooling lotivel and Pressure Loss Variation With Rotor Inlet Temperature

2-6 First Stage Turbine Blade

2-7 Second Stage Turbinc Vane

2-8 Second Stage Turoine Blade

2-9 First Stage Turbine Blade Cooling Flow Rate for Muximum Metal Temperature

2-10 First Stage Turbine Blade Cooling Flow Rate for Constant Life 16

2-11 - First Stage Blade Maximum Metal Temperature for Design Creep Life

3-1 Simple Cycle Configuration for Uncoated Base Engine

3-2 Stcam System for Base Engine Configuration

3-3 Steam System for Increased_Life Engine Configuratio.1 (Uncoated)

3-4 Performance Optimizatio,

3-5 Optimized Simple Cycle Configuration for Thermal Barrier Coated FTSO

3-6 Optimized Combined Cycle Configuration for Two Thermal Barrier Coated FT50 Engines With 30K Hrs. Life

5-1 Thermal Barrier ('oating Developmert Plan Schedule

5.2 Bill-of-Material Applications of Thermal Barrier Coutiıgs 


\section{LIST OF ILLUSTRATIONS (Cont'd)}

Figure

Title

Page No.

5-3 Phase Il Coating.Technology Development, Task 1 Pricess Techrology

42

5-4 Phase II. Coating Technology Developinent, Tusk 2 12urability Technology

5.5 Pliase li Coating Technology Development, Task 3 Frosion Corrusion Techmology

5-6 Phast lil Design Support Technology

5-7 Flements of the Plasma Spray Process

40 


\section{CONCLUSIONS AND RECOMMENDATIONS}

The application of a thermal barrier coating to the hot section components of a high temperature gas turbine engine offers the potential for significant design and performance im:provements with resulting ecc,slomic advantages. A study was conducted to evaluate the design, performance and conomic effects of applying a thermal barrier couting to the hot section components of the ET,50 industrial gas turbine. This program also included the definition of a research and technology plan to achieve a commercial demonstration of an industrial gas turbine engine with thermal barrier coated hot section components.

The thermal barrier coating evaluated is composed of an yttria stabilized zirconia material bonded to the hot scition component over a NiCrAlY coating. The total thickniss of the coating is 0.48 micrometers $(19$ mils) and is applied using an are plasma spray pocess. The benefits of this thermal barrier coating were studied by comparing the design requirements and economic characteristics for a high temperature industrial gas turbine. the FTSOA-4, and an FT50 type engine modified to use the the rmal barrier coating on its hot section components. The major design change permitted by the use of the theminal barrier coating was the substitution of simpler convective cooling schemes for the more complex film cooling schemes. The related cooling thow reductions resulted in a $4 \%$ heat rate improvement for the thermal barrier coated design relative to an uncoated design with equivalent structural life ( 30,000 hours). Other design advantages included the use of conventional burner materials and the potential for an improved bumer exit temperature profile which results in increased turbine life. Engine performance was optimized for the thermal barrier coated design by trading firing temperature levels with coolant flow requirenents necessary to achieve the 30,000 hour structural design criteria. The performance level achieved was lirnited by the uncooled FT50 power turbine temperature constraint imposed by the 30.000 hour structural requirement.

The performance evaluation included consideration of a simple-cycle configuration (single FT50 engine) and a combined-cycle configuration (2 FT50 engines and one two-pressure steam bottoming cycle). The heat rate improvement for both the simple-cycle and the combined-cycle configurations using thermal barrier coatings was about $4^{\prime \prime}$ and there was an improvement in specific power of about $13 \%$. The combined-cycle configuration showed a slightly larger improvement in both categories. The major differences between the simple and combined-cycle configurations are apparent when considering fucl consumption. Over the 30,000 hour operating lifetime, when compared on an equal total electric energy power production basis, the fuel savings for a coated engine simple-cycle system versus an uncoated engine system approaches 196,000 barrels of oil. For the combined-cycle system, up to 410,000 barrels of oil are saved by using a coated engine combined-cycle system versus the uncoated engine combined-cycle system. These savings are significant and, when considering the residual fuel cost, amount to as much as $\$ 5$ million. The maintenance and refurbishment costs associated with the thermal barrier coating are simall relative to the fuel and capital costs and have essentially an insignificant effect on total power cost. Reduced electrical power production costs are estimated near $6 \%$ relative to an uncoated FT50 type engine. 
A development program for thermal barrier coatings is recommended to conduct the significant research and technology activities necessary to achieve a commercial demonstration in a high temperature industrual gas turbine engine. This program is composed of four phases; Current Data Bank, Coating Technology, Design Support Technology, and Engine Programs.

The first phase, already in progress through United Technologies Corporation (UTC) research programs, is planned to draw on current UTC thermal barricf coating experience tor combustors and extend this technology for turbine applications. This.phase is not specifically an item. to be funded under the suggested pian, but rather is an on-going UTC supported effort that will provide inputs to help guide this program in an efficient, cost effective manner. The second phase comprises the major research and technology activities of Process Technology, Durability Technology, and Erosion-Corrosion Technology. Improved thermal stress control of increased durability coating ap the main objective for the Process Teclinology rask. Verification of increased durability for the best coating process application in a thermal fatigue environto determine the coatings resistance or reaction A coating erosion-corrosion investigation identify coating improvements is the primary objective for tisk fuels with an evaluation to aimed at developing the design toos and objective for task three. The third phase is of these are developinedesign tools and measuring the coating material properties. Examples and mechanical property a a coating life prediction system or the measurement of thermal demonstration of the thertata for design use. Phase four, the final activity, is the commercial gas turbine. 


\subsection{INTRODUCTION}

Thermal barrier coatings have been identified as having potential benefits when applied to high temperature gas turbines. The insulating effect of thermal barrier coatings as well as its potential for increased corrosion resistance can improve engine performance and increase component life. Since thermal barrier coating technology is applicable to all cooled gas turbines, NASA has iritiated a limited experimental and study effort to assess the potential of the thermal barrier coating in a high temperature utility gas turbine application. This report documents a study to evaluate the benefits of thermal barrier coatings as applied to a high temperature industrial gas turbine. This study was sponsered by the Energy/ Research and Development Administration under Interagency Agreement No. E (49-28)- 1022.

\subsection{OBJECTIVES}

The objectives of this program were to evaluate the extent to which ine application of thermal barrier coatings to cooled high temperature industrial gas turtine components would: (1) permit redesign to increase component life by substituting convection cooling for film cooling and by lowering metal temperatures, (2) allow trade-off of increased turbine inlet temperature and coolant requirements to optimize heat rate, and (3) reduce electrical power production costs for both simple-cycle and combined-cycle system configurations. An additional objective was the formulation of a preliminary research and technology program plan directed toward achieving a commercial engine demonstration of the benefits of thermal barrier coated cooled components.

\subsection{PROGRAM}

The objectives of this program were accomplished in four technical tasks, which are briefly described below.

Task I - Heat Transfer Analysis - This study was conducted to determine the coolant requirements for convectively cooled, thermal barrier coated FT50 hot section components. The thermal barrier coating assumed for this analysis was a $0.1 \mathrm{~mm}(0.004$ inch) NiCrAlY bond coat and a $0.38 \mathrm{~mm}(0.015 \mathrm{inch})$ yttria-stabilized zirconia overcoat.

Task Il - Performance Calculations - This portion of the study program evaluated the system trade-offs between turbine inlet temperature, coolant flow rate, metal temperature, heat rate and specifir power. Calculations were made for a simple-cycle configuration and a combined-cycle, which included a steam cycle. Both "clean" light distillate and "dirty" residual fuels were considered in the performance calculations.

Task III - Impact Assessment - This task consisted of an electrical power production cost evaluation for the FT50 engine system using thermal barrier coatings. A capital cost analysis was included for simple-cycle and combined-cycle power stations. This evaluation considered estimated costs for redesign and initial coating application, and operating and maintenance costs for refurbishment of the thermal barrier coated hot section components. 
Task IV - Preliminary Development Plan - Under this task, the significant research and technology activities were identified to achieve a commercial demonstration of a high temperature industrial gas turbine with thermal barrier coatings. The development plan also includes preliminary schedules for the technology advances and the component design modifications required.

\subsection{FT50 ENGINE DESCRIPTION}

The FT50 is a large high performance industrial gas turbine engine. It's general arrangement is a two spool gas generator configuration with a free power turbine. A cross-section of the FT50 is shown in Figure 1-1.

An 18: 1 compression ratio is achieved by a 7 stage low-pressure compressor driven by a single stage low-pressure turbine, and a 10 stage high-pressure compressor driven by a sing). stage high-pressure turbine. The two spool design was selected to meet the compression ratio requirement with high efficiency and without the cost and mechanical complexity penalties associated with the variable geometry which would have been necessary with a single spool arrangement. The separate two stage power turbine provides the capability to have two gas turbines drive a single generator, to rematch the engine for maximum power under specific climatic conditions (this is possible since gas generator speed is not dependent on free turbine rotational speed), and to service both 60 cycle and 50 cycle markets.

The FT50 incorporates advanced cooling techniques to keep component metal temperatures low for long life while operating at high gas temperatures for high efficiency. Modular construction is featured to minimize maintenance cost and down time. 


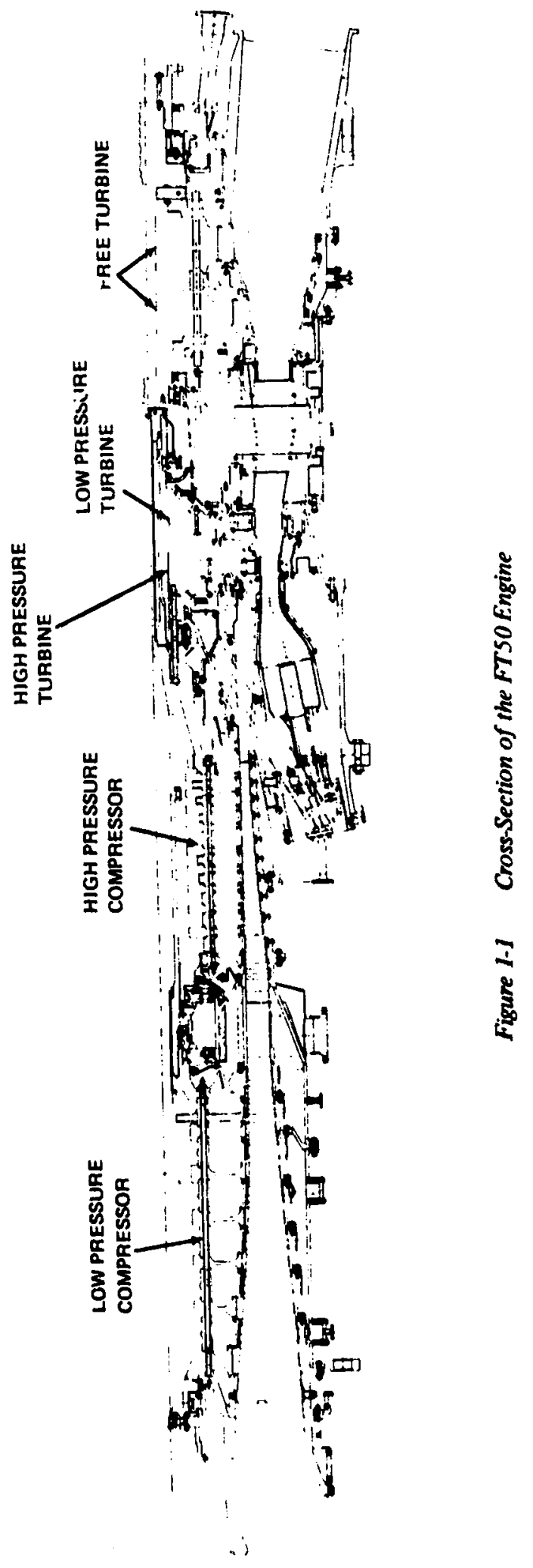




\subsection{HEAT TRANSFER AND LIFE ANALYSIS}

The purpose of this heat transfer and life analysis is to identify advantages and problem areas related to adding a thermal barrier coating to the hot sections of FT50A-4 gas turbine engines. The specified coating is $0.10 \mathrm{~mm}(0.004 \mathrm{in})$ NiCrAlY bond coat with a $0.38 \mathrm{~mm}$

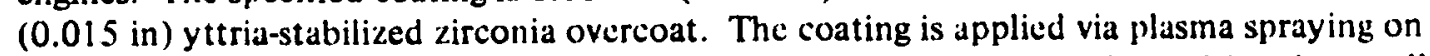
turbine blades, vanes and plat forms as well as combustion chamber and transition duct walls. One dimensional, steady state heat balances were used throughout the analysis which incorporated the coating thermal properties as identified in Appendix A. The low conductivity of the thermal barrier coating produced a high temperature difference between ccating surface temperature and metal temperature. The temperature difference and, therefore, coating effectiveness was greater for areas with higher heat flux since the temperature difference is proportional to the heat flux through the coating. The high costing surface temperature reduces the heat flux substantially by reducing both the convective and radiative thermal loading.

\subsection{COMBUSTOR ANALYSIS}

As turbine designs using higher gas temperatures are sought, the requirements for burner combustor air and cooling air increase. This, in turn, reduces the dilution air available for tailoring the exit gas temperature profile. Without a change in geometry to reduce the surface area to be cooled (i.e., a shorter bumer or change from can to annular design), material, cooling techniques and/or a thermal coating, insufficient air is available to meet the durability requirements of uprated engines.

\subsubsection{Base Combustor}

The FT50A-4 combustor design incorporates an advanced alloy that permits operation at $1144^{\circ} \mathrm{K}\left(1600^{\circ} \mathrm{F}\right)$ wall temperatures while meeting durability requirements of 10,000 hour creep/low cycle fatigue life with refurbishment capability to 30,000 hours. The base design includes a magnesium zirconate coating on a special combustor alloy, MERL 72, to achieve the desired wall temperature. The combustor airflow distribution is summarized below.

$\begin{array}{ll}\text { Primary combustion air } & 29.5 \% \\ \text { Combustor cooling } & 25 \% \\ \text { Transition duct cooling } & 21 \% \\ \text { Vilution air } & 24.5 \%\end{array}$

In order to reduce combustor wall temperatures to $1088^{\circ} \mathrm{K}\left(1500^{\circ} \mathrm{F}\right)$, as requested by NASA for the purpose of this study, cooling flow requirements would increase by $5 \%$. This air would be subtracted from the dilution air leaving only $19.5 \%$ air to tailor the radial gas temperature profile and reduce burner gas hot spots. Reducing the dilution air would increase hot spot temperature and result in higher pattern factors and luwer turbine durability. Pattern factor is calculated using the following equation: 


$$
P F=\frac{T_{\text {HOT SPOT }} T_{5}}{T_{5}-T_{4}}
$$

The transition duct design does not have magnesium zirconate coating since the fouver cooling is sufficient to achieve acceptable wall temperatures although cooling air requirements are high. The louver cooling works by laying a thin film of cool air parallel to the liner surface, see Figure 2-1. Air is introduced in a series of small holes on a raised step (knuckle). There are minimum hole size requirements to facilitate fabrication and prevent plugging, and maximum hole spacing limitations to insure that the coolant enters the combustor as a continuous film, and not descrete jets. Since the hole sizing and spacing provides the minimum possible cooling level, there is no reason to acd coating.

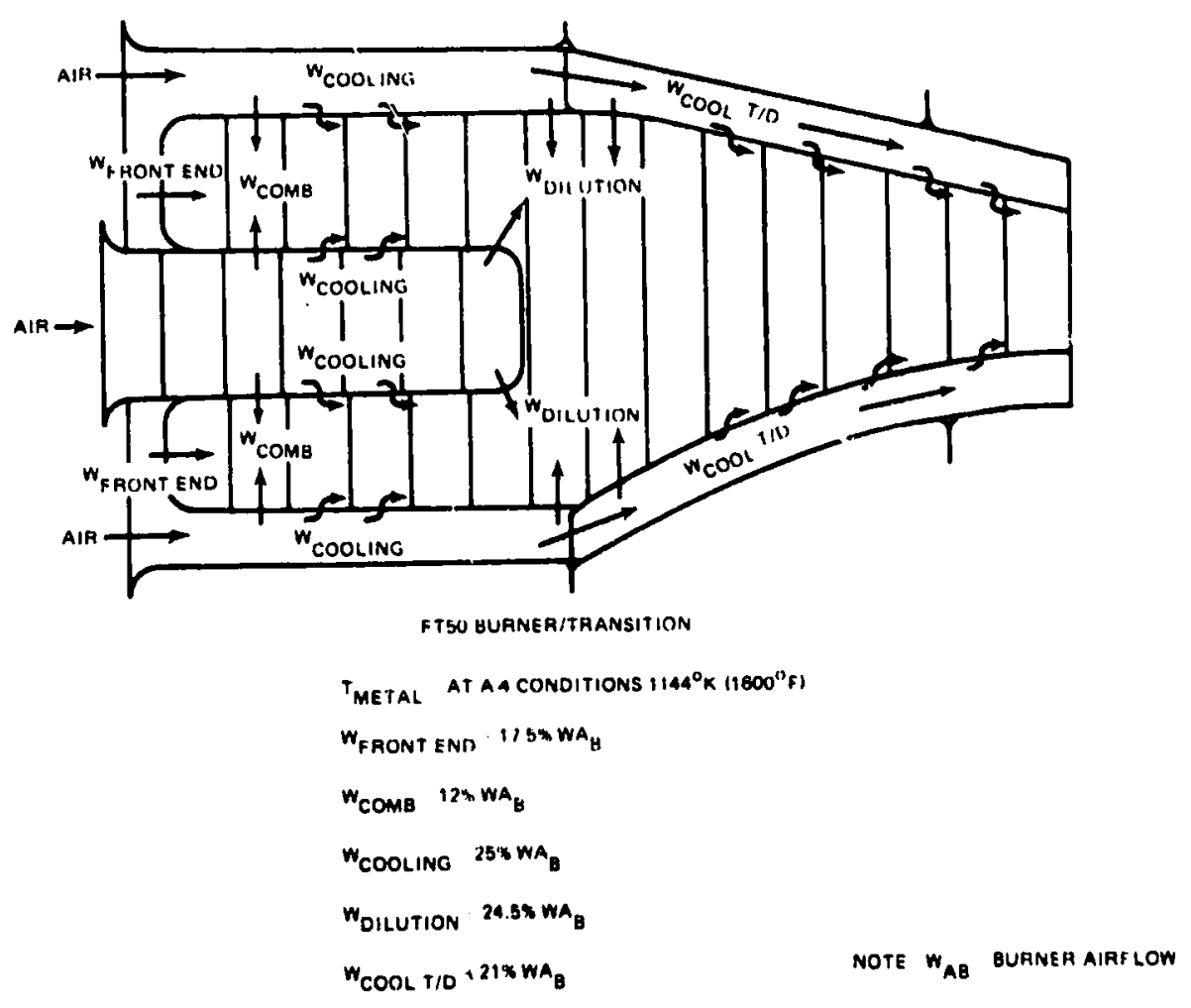

\section{Figure 2-1 Base Engine Design}

\subsubsection{Thermal Barrier Coated Combustor}

As an alternative design, this study evaluated the use of a yttria stabilized rirconia coating on conventional Hastelloy $X$ material for both the burner surfaces and the transition duct to meet the durability requircments. The design criteria is the sume as the base design, 10,000 hours creep/low cycle fatigue inturaction life with the capability for refurbishment to extend component life to 30,000 hours. The thermal calculations were performed using standard P\&WA design programs with appropriate boundary conditions. 
As shown in Figure 2-2, the combustor wall cooling is the same as the base FT50 A-4 design for $1144^{\circ} \mathrm{K}\left(1600^{\circ} \mathrm{F}\right)$ metal temperature. If filin cooling is increased from $25 \%$ to $30 \%$ of burner air flow, combustor inetal temperature can be reduced to $1088^{\circ} \mathrm{K}\left(1500^{\circ} \mathrm{F}\right)$. The dilution air flow ( $W_{\text {Dilution }}$ ) available for either wall temperature case, with the convectively cooled transition duct, is greater than the base 1:T50A-4 dilution flow. Therefore, the thermal barrier coated design can be cooled to $1088^{\circ} \mathrm{K}\left(1500^{\circ} \mathrm{F}\right)$ and still have a more than adequate supply of dilution air for tailoring the gas temperature profile entering the turbine.

One quest:on to be answered is whether the required convective heat transfer coefficients for convective cooling can be achieved with a realistic geometry and the available pressure drop. Figure 2-3 shows the required transition duct shroud heat transfer coefficients, at FT50A-4 conditions, to produce a given-wall temperature in the transition duct, with and without coating. The uncoated case is beyond reach. For the ccated case, the effect of wall emissivity is seen to be small because at the relatively low gas temperatures of the transition duct, convection is the primary heat load component.

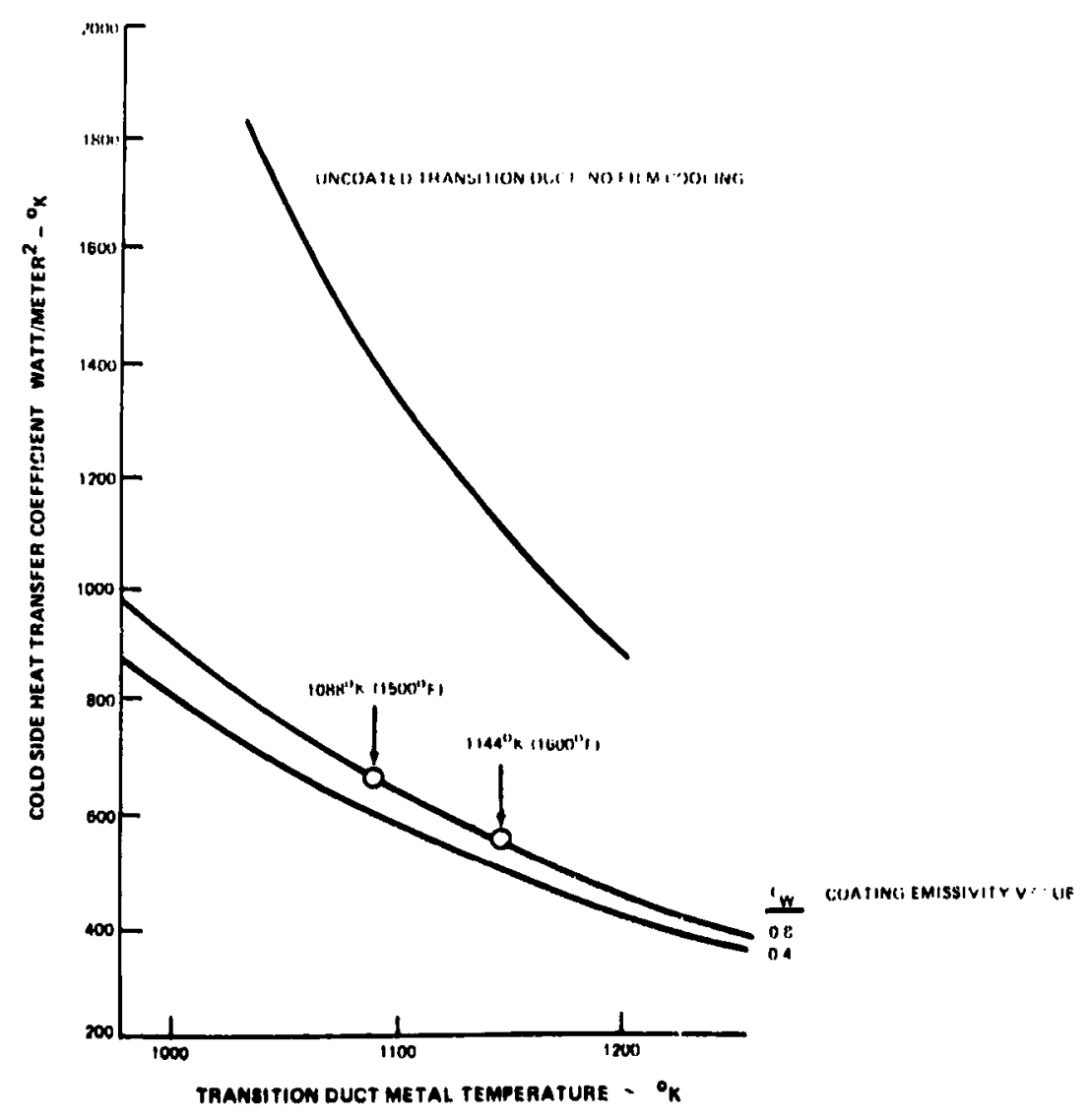

Figure 2-3 Heat Transfer Coefficient Requirements for Transitton Duct 
The maximum heat transfer coefficient required is approximately $1000 \mathrm{watt} / \mathrm{m}^{2} .{ }^{\circ} \mathrm{K}$ $\left(5674 \mathrm{Btu} / \mathrm{ft}^{2} \mathrm{hr}-{ }^{\circ} \mathrm{F}\right)$. This level can be achieved with a $1.5 \mathrm{~cm}(0.6 \mathrm{in})$ high annular passage around the transition duct for the available-pressure-drop.

Therefore, a thermal barrier coated combustor/transition duct design will allow reduced. wall temperatures and increased dilution air flow compared to the base FT50A-4 ' 2 sign. The increased dilution flow represents the capability to improve the base pattern factor and to tailor the turbine entry gas profile to maximize turbine durability for a given turbine inlet temperature.

\subsection{TURBINE ANALYSIS}

The turbine blade and vane cooling schemes were designed incorporating the insulative properties of the thermal barrier coating. Cooling sciteme simplifications were made, where possible, to design convective cooling configurations in place of fil $m$ cooling configurations to eliminate the need for drilling coolant holes. The components evaluated were the firststage turbine vane and plat forms, the first-stage blade, and the second-stage vane and blade. An example of a first-stage vane configuration with leading edgc film cooling, also descrioed as showerhead cooling, is shown in Figure 2-4. Showerhead cooling consists of an aray of . leading edge cooling holes which face the on-coming flow and provide protection to the structure by the coolant film that is ejected. Eliminating showerhead cooling holes and designing cooling schemes with simple convective cooling configurations combined with thermal barrier coatings results in simpler design, and eliminates the concern over showerhead hole plugging.

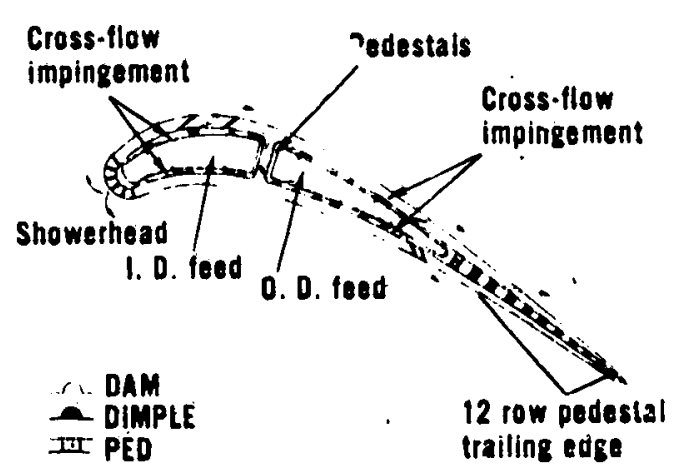

(a) Uncoated vane

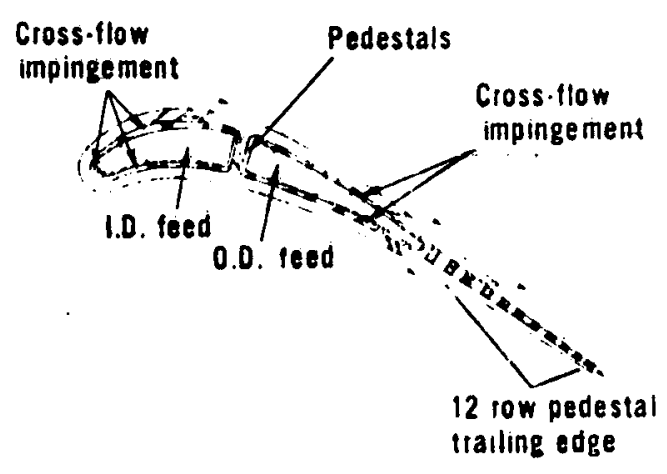

(b) Coated vane

Figure 2-4 FTs0 First Stage Turbine Vane 
The base FT50A-4 gas generator turbine was designed without a thermal barrier coating and was limited at $1144^{\circ} \mathrm{K}\left(1600^{\circ} \mathrm{F}\right)$ maximum metal temperatures to avoid severe corrosion penalties. With the redesign of the turbine to incorporate the thermal barrier coating, the corrosion life was assumed to be removed because the coating was assumed to have unlimited cor osion resistance. The design criteria for the thermal barrier coated turbine was a $1 \%$-creep life of 30,000 hours.

\subsubsection{First Vane Analysis With Thermal Barrier Coating}

Figure 2-4a shows the base ET50A-4 first vane cooling configuration. The leading edge has a show:rhead cooling scheme and the pressure and suction walls are cooled with a combination of film cooling and internal cross flow impingement. The trailing edge is film cooled and has internal pedestals. The cooling flow rates are-given in Table 2-I.

TABLE 2-I.

FIRST VANE COOLING FLOWS

FT50A-4 Conditions - Rotor Inlet Temperature $=1455^{\circ} \mathrm{K}\left(2160^{\circ} \mathrm{F}\right)$

Uncoated FT50A-4 Vane

Thermal Barrier Coated Vane

$$
\begin{array}{lll}
\mathrm{T}_{\text {metal }}=1144^{\circ} \mathrm{K}\left(1600^{\circ} \mathrm{F}\right) & \mathrm{T}_{\text {metal }}=1088^{\circ} \mathrm{K}\left(1500^{\circ} \mathrm{F}\right) & \mathrm{T}_{\text {metal }}=1144^{\circ} \mathrm{K}\left(1600^{\circ} \mathrm{F}\right) \\
\mathrm{W}_{\text {Airfoil }}=8.0 \% \mathrm{WA}_{\mathrm{E}} & \mathrm{W}_{\text {Airfoil }}=3.9 \% \mathrm{WA}_{\mathrm{E}} & \mathrm{W}_{\text {Airfoil }}=3.0 \% \mathrm{WA}_{\mathrm{E}} \\
\mathrm{W}_{\text {Platform }}=3.36 \% \mathrm{WA}_{\mathrm{E}} & \mathrm{W}_{\text {Platform }}=2.85 \% \mathrm{WA}_{\mathrm{E}} & \mathrm{W}_{\text {Platform }}=2.5 \% \mathrm{WA}_{\mathrm{E}} \\
{ }^{\mathrm{W}_{\text {Total }}}=11.36 \% \mathrm{WA}_{\mathrm{E}} & \mathrm{W}_{\text {Total }}=6.75 \% \mathrm{WA}_{\mathrm{E}} & \mathrm{W}_{\text {Total }}=5.5 \% \mathrm{WA}_{\mathrm{E}}
\end{array}
$$

Figure $2.4 \mathrm{~b}$ shows the thermal barrier coated version of the first vane with the leading edge showerhead cooling holes deleted. In order to cool this leading edge area, an array of impingement holes has been incorporated in the front insert tube. The impingement jets give internal heat transfer coefficients high enough to cool the coated leading edge area. Due to high heat fluxes along the vane suction side, film cooling plus internal impingement is still needed to maintain acceptable wall temperatures, although less cooling flow is necessary for the thermal barrier coated design (see Table 2-I). The external pressure side heat transfer coefficients are much lower than the suction side so that no film cooling is rieeded on the front portion of the vane. Toward the aft end of the pressure side of the airfoil, the external heat transfer coefficient increases until film cooling is needed to maintain acceptable wall temperatures in the trailing edge region. The pedestal cooled trailing edge region has coolant flow rates similar to the base FT50A-4 values at that location. The thermal barrier coated airfoil cooling is greatly reduced from base. FT50A-4 levels as presented in Table 2-l. Vane platform cooling is accomplished with multipass impingement cooling plus film cooling for both the base FT5OA-4 and the thermal barrier coated configuration. The platforms will be coated so that reduced platform film cooling will be possible for the coated configu- 
ration and the internal multipass.impingement scheme will be the same as the base FT50A-4 configuration. The reduction in platform cooling air is also given in Table 2-1 for the thermalbarrier coated configuration.

In order to achieve a $1088^{\circ} \mathrm{K}\left(1500^{\circ} \mathrm{F}\right)$ first vane maximum metal temperature without the thermal barrier coating, total cooling air must be increased approximately $20-40 \%$ over the vane cooling level at $1144^{\circ} \mathrm{K}\left(1600^{\circ} \mathrm{F}\right)$. The cooling level is a function of both rotor inlet . temperature and pattern factor as shown in Figure 2-5. The metal temperatures indicated are the maximum metal temperature at the hot spot location and include effects of engine deterioration, trim and pattern factor for the nominal coating thickness. Note that an increase of about $67^{\circ} \mathrm{K}\left(120^{\circ} \mathrm{F}\right)$ in high pressure turbine rotor inlet temperature $\left(T_{t 5.1}\right)$ can be tolerated-with no change in conling or metal temperature if pattern factor can be reduced (hot spot temperature reducidi) to a value of 0.3 from the base value of 0.4 . The lower burner transition duct cooling levels, obtained with the thermal barrier coating make such a reduction in pattern factor a strong possibility.

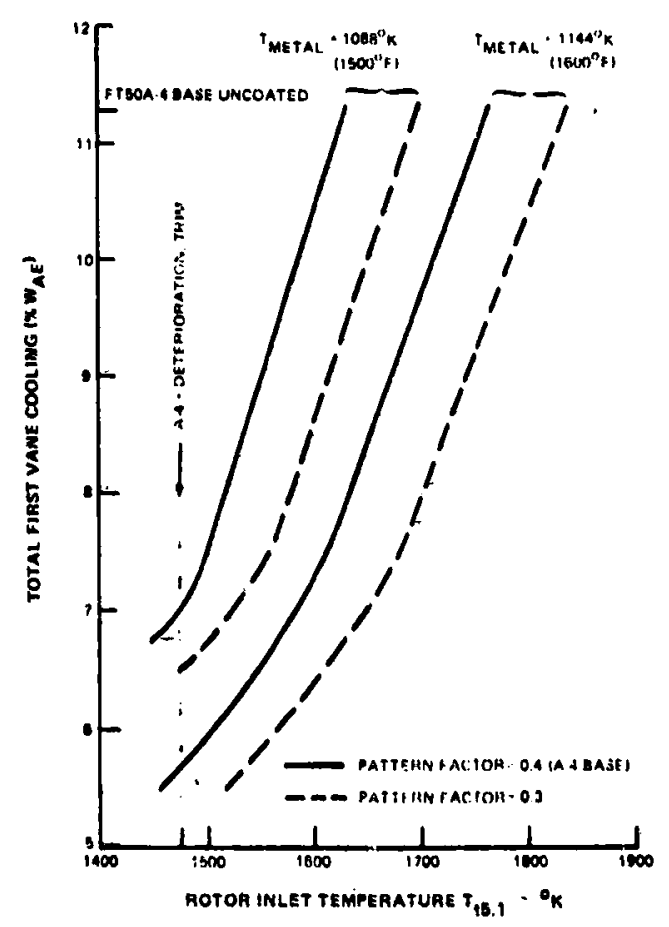

Figure 2.5 Coated Vane Cooling Level with Rotor inlet T'mperature

A slight increase in performance can be gained by reducing vane cooling due to a reduction in the pressure losses associated with injecting a low velocity cooling film into a high velocity gas stream. The pressure loss estimate was hased on pressure loss increasing $0.1 \%$ for 


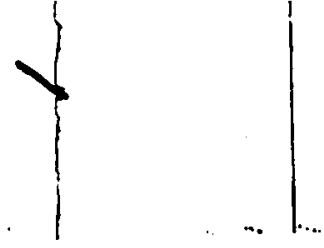

every $1 \%$ cooling change in the high velocity regions of the airfoil where the velocity difference between cooling film and mainstream is the greatest. The impact on overall performance is small but not insignificant since this effect will ten 1 to counteract the effect of increased airfoil drag due to thermal barrier coating i oughness.

The final result of the first vane analysis showed that the $1088^{\circ} \mathrm{K}\left(1500^{\circ} \mathrm{F}\right)$ metal temperature, which is desirable from a durability viewpoint, can be obtained with the thermal barrier coated design at rotor inlet temperatures substantially greater than the FT50A-4 design conditions.

\subsubsection{First-Stage Blade and Second-Stage Airfoil Analysis}

The requirements for film cooling were eliminated in the first-stage blade and the secondstage vane with the addition of the thermal barrier coating. Coolant flow reductions as high as $58 \%$ are realized with the thermal barrier coated designs. Figures $2-6$ thru $2-8$ show the uncoated FT5OA-4 design and the redesigned thermal barrier coated designs at two metal temperatures, $1088^{\circ} \mathrm{K}\left(1500^{\circ} \mathrm{F}\right)$ and $1144^{\circ} \mathrm{K}\left(1600^{\circ} \mathrm{F}\right)$, with their required cooling flows.

ROTOR INLET TEMPERATURE $=1455^{\circ} \mathrm{K}\left(2160^{\circ} \mathrm{F}\right)$

MATERIAL $=$ INCO 738

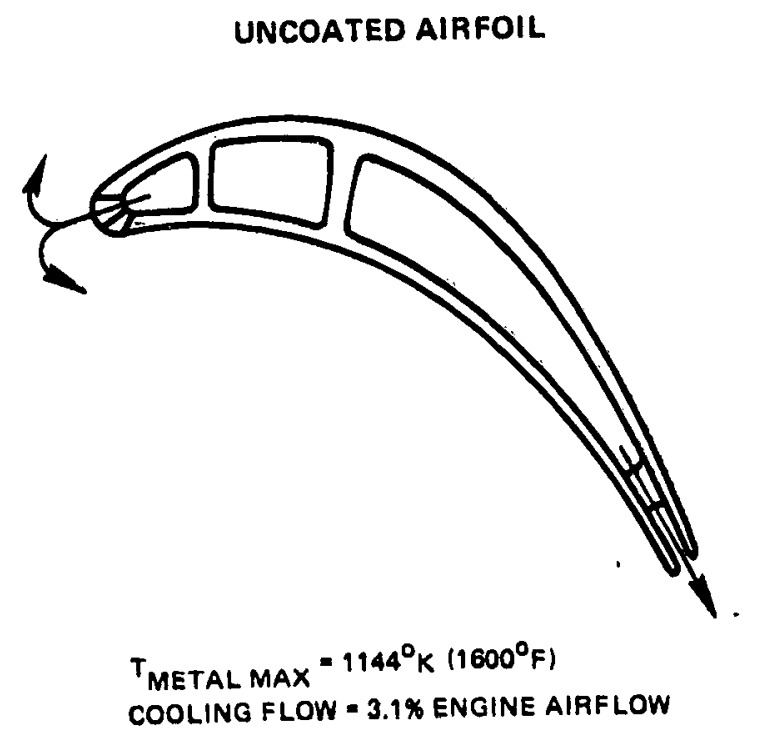

THERMAL BARRIER COATED AIRFOIL

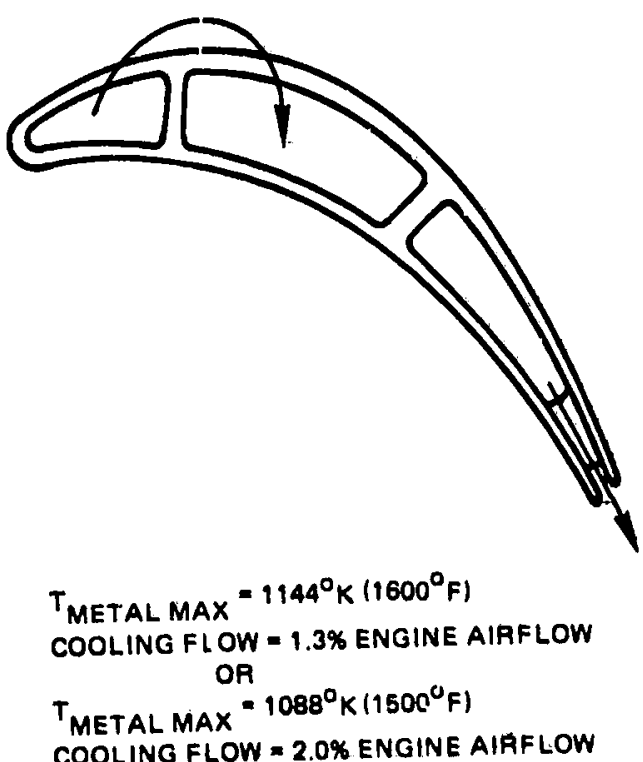

Figure 2.6 First Stage Turbine Blade 
The FT50A-4 gas generator turbine has two essential design life critetia: (1) Maximum metal temperature equal to or below $1144^{\circ} \mathrm{K}\left(1600^{\circ} \mathrm{F}\right)$ to minimize hot corrosion, and (2) a $1 \%$ creep life of 30,000 hours at Peak Power, $313^{\circ} \mathrm{K}\left(104^{\circ} \mathrm{F}\right)$ day. Two options are possible to take advantage of the coating's insulative qualities while still adhering to these design criteria. These are reduced coolant usage or increased cycle temperature. First blade cooling flow rates as a function of rotor inlet temperature were calculated for constant.maximum metal temperature (Figure 2.9) and for constant life (Figure 2-10) in order to evaluate engine performance benefits. (Similar calculations were conducted for the-second vane.and second. blade.) Table 2-ll summarizes the cooling flow requirements of the coated and uncoated FTSOA-4 airfoils for the maximum metal.temperature design criteria and Table 2-1ll summarizes the cooling flow requirements for the coated airfoils satisfying the 30,000 hour creep life design criteria. As can be seen from the two tables, thermal barrier coated airfoils require more cooling flow at the FTSOA-4 design rotor inlet $\left(T_{5.1}=1455^{\circ} \mathrm{K} .\left(2160^{\circ} \mathrm{F}\right)\right)$ to satisfy the 30,000 hour.creep life criteria than they do to satisfy the $1144^{\circ} \mathrm{K}\left(1600^{\circ} \mathrm{F}\right)$ maximum metal temperature design criteria. Thus the creep life design criteria is limiting for the thermal barrier coated FTSOA-4 airfoils. The actual maximum metal temperature of a thermal barrier coated FT50A-4 airfoil satisfying the creep life design criteria becomes a function of rotor inlet temperature as is shown in Figure 2-11 for the first blade.

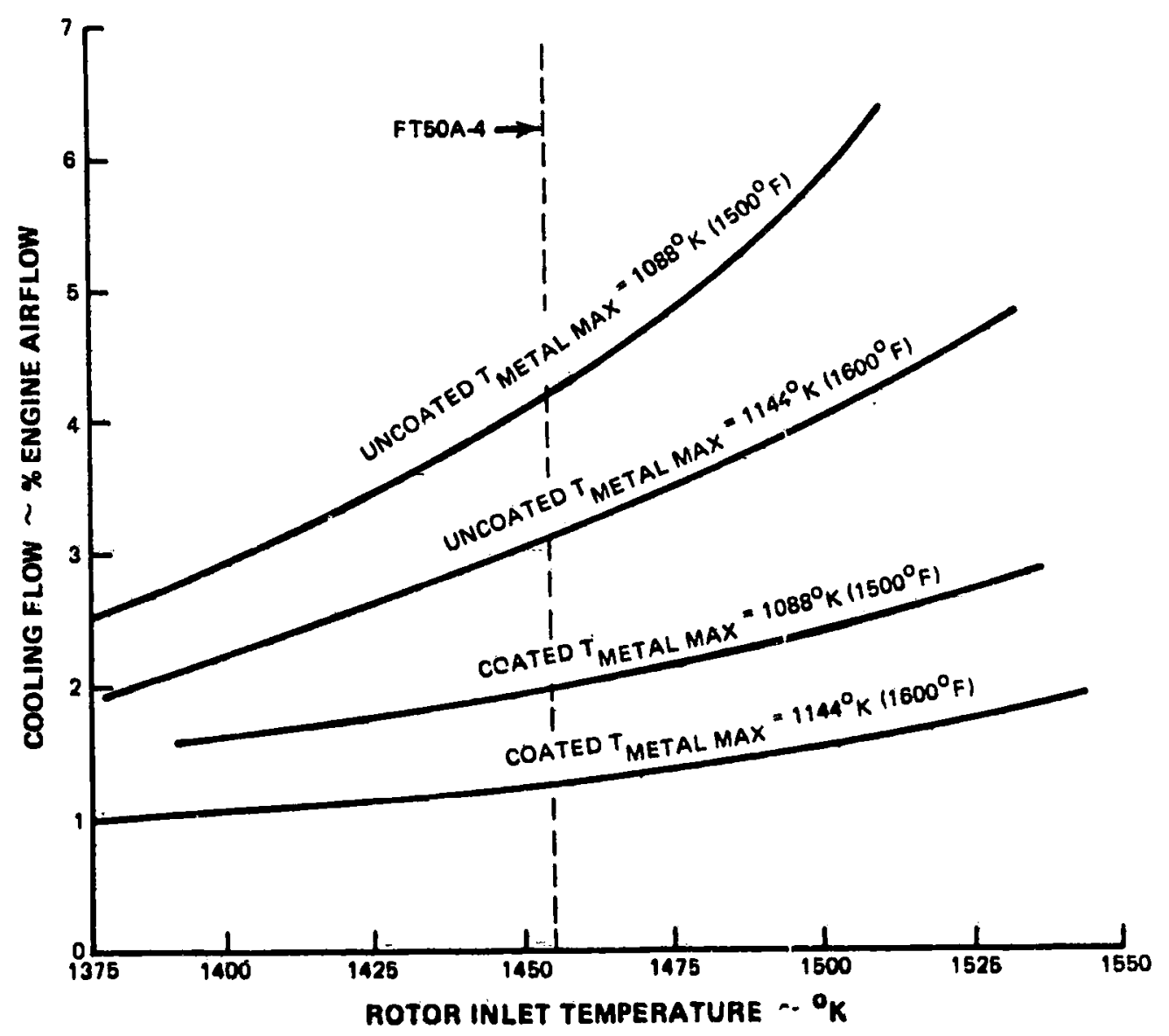

Figure 2.9 First Stage Turbine Blade Cooling Flow Rate for Maximum Metal Temperiture 
Thermal barrier coatings in the "as sprayed" state have surface roughness levels measured between 6.35 to $8.89 \times 10^{-6} \mathrm{~m}$ ( 250 to 350 micro inches). Conventional metallic coatings have "as deposited" surface roughness levels measured near $1.78 \times 10^{-6} \mathrm{~m}$ (70 micro inches). However, experience-has demonstrated that after relatively short run periods, the metallic soating surfaces increase in roughness level due to dirt, oxidation, erosion, and corrosion. Lirnited experience with thermal barrier coatings after short run periods has not indicated increased roughness. Jevels.

Assuming that initial metallic coating and thermal barrier coating surface roughness levels remain-unchanged during operation, a performance comparison can be calculated to reflect the aerodynamic effects and the heat transfer effects $d=$ to the roughness difference. The uncocled turbine component efficiency penalty calculated due to the increased surface roughness of the thermal barrier is $0.5 \%$.

In addition, the higher thermal barrier coated roughness increases the turbulent external heat transfer coefficient which results in a $10 \%$ increase in coolant requirement. However, the use of the thermal barrier coating decreases the heat flux into the airfoil which reduccs the requirement for coolant relative to the coolant required for an airfoil without a thermal barrier coated by $50 \%$ so that there is still a substantial reduction in net heat load. Also the lower net coolant requirement reduces the aerodynamic mixing loss from injecting the coolant into the main gas stream, for example, trailing edge discharge mixing losses.

The aerodynamic loss differences in the turbine nearly cancel the penalty due to the surface condition. The net effect of reduced heat flux and resulting thermal cycle benefits, due to the reduced coolant requirement, remains significant. Additional performance benefits are possible if smoothing of the coating surface can be accomplished through coating processing techniques. These additional.benefits are discussed in NASA TM-X3191.

All of these aerodynamic and thermodynamic effects have been incorporated in the performance results presented in Section 3.0. 


\subsection{PERFORMANCE ANALYSIS}

An analysis to define the effects of thermal harrier coated hot section components on performance was made using a sophisticated powerplant performance analysis program called "State-of-the-Art Performance Program" (SOAPP). The program is hased on a modularized representation of the system components, permitting virtually complete fredom.in defining the power system configuration. The program is capable of analyzing the steam bottoming cycle as well as the gas turbine cycle and will calculate performance for variations in turbine rotor inlet temperature, cooling airtluw, cooling air distribution. component characteristics, boiler pressure, and steam tlow rate, all of which were used in this study. The FT50A-4 simulation, with and without an appropriate steam bottoming cycle, was used as the base from which the thermal harrier coatings were calculated.

\subsection{PERFORMANCE SUMMARY}

The FT50A-4 compressor operating point was held constant throughout the study of tile various coated and uncoated turbine configurations. The base engine was the FT50A-4 uncoated design operating at a high pressure turbine rotor inlet temperature of $1455^{\circ} \mathrm{K}\left(2160^{\circ} \mathrm{F}\right)$ and with turbine cooling flow set to maintain turbine metal temperatures at a maximum of $1144^{\circ} \mathrm{K}$ $\left(1600^{\circ} \mathrm{F}\right)$. The lrase engine turbine airfoil life at the $1144^{\circ} \mathrm{K}\left(1600^{\circ} \mathrm{F}\right)$ maximum metal temperature was 10,000 hours. An increased life uncoated design, also operating at a rotor inlet temperature of $1455^{\circ} \mathrm{K}\left(2160^{\circ} \mathrm{F}\right)$, was requested for comparison by NASA which had coolant flow required to maintain turbine airfoil maximum temperatures at $1088^{\circ} \mathrm{K}$ $\left(1500^{\circ} \mathrm{F}\right)$. This uncoated design had 30,000 hours creer life. Both the base engine and the increased life designs are corrosion limited.

An optimization study was conducted to determine the best engine performance with a thermal barrier coated hot section achieving the 30,000 hour life to $1 \%$ creep as a structural criteria. The thennal barrier coating was assumed to have a corrosion life greater than 30,000 hours.

Improved performance was attained with increased turbine rotor inlet temperature; however, the level was limited by the power turbine inaterials. At power turbine inlet temperatures greater than $1088^{\circ} \mathrm{K}\left(1500^{\circ} \mathrm{F}\right)$, the puwer turbine life does not meet the 30,000 hour criteria. The optimized thermal barrier coated engine performance resulted in a lieat rate improvement of $3.8 \%$ over the uncoated engine designed at a $1088^{\circ} \mathrm{K}\left(1500^{\circ} \mathrm{F}\right)$ metal temperature. Both the thermal barrier coated engine and the $1088^{\circ} \mathrm{K}\left(1500^{\circ} \mathrm{F}\right)$ metal temperature uncoated engine meet the 30,000 hour life criteria. The optimized theimal barrier coated engine had a $1.5 \%$ heat rate improvement over the uncoated turbine $1144^{\circ} \mathrm{F}\left(1600^{\circ} \mathrm{F}\right)$ metal temperature base engine as well as incriased turbine life (10,000 hours to 30,000 hours). ihe thermal barrier coatings resulted in sinilar improvements in the combined cycle configuration.

H:-oner levels of engine performance would be possible if the power turbine constraint could be relaxed through use of advanced materials or cooled airfoil design. This example is typical of the limitations incurred from applying new technology features into an established engine design. The optimum benefits for a new technology feature can only be realized when considered in the design philosuphy during preliminary design phases. 
Table 3-I summarizes the improvements resulting from the thermal barrier coatings comparing to the buse uncoated engine and the increased life uncoated engine.

TABLE 3-1

ESIIMATED PERFORM ANCE IMP ROVEMFNTS WITH THERM AL BARRII:R COATINGS ON BURNI:R AND TURBINE

ISO Conditions

$288^{\circ} \mathrm{K}\left(59^{\circ} \mathrm{F}\right)$ Ambient .

Sea Level

Base Engine

Comparison*

Increased Life Engine

Comparison *

HEAT RATE

SIMPLE CYCLE

COMBINED CYCLE

\author{
SPIECIFIC POWHR \\ SIMPLE C'YC'LE COMBINIDD CYC'LE
}

$\begin{array}{llll}-1.5 \% & 2.1 \% & +7.1 \% & +7.8 \% \\ -3.8 & 4.1 \% & +12.8 \% & +13.4 \%\end{array}$

-Coated engine ( $30 \mathrm{k} \mathrm{hr}$ life) relative to uncoated base engine (FTSOA $4, \mathrm{~T}_{\max }$ metal $=1144^{\circ} \mathrm{K}\left(1600^{\circ} \mathrm{F}\right)$ )

- Coated increased life engine ( $30 \mathrm{k} \mathrm{hr}$ life) relative to uncoated increased life max metal

$\left.1088^{\circ} \mathrm{K}\left(1500^{\circ} \mathrm{F}\right)\right)$

Note: Rotor inlet temperature for the coated engine $=1480^{\circ} \mathrm{K}\left(2204^{\circ} \mathrm{F}\right)$, for the uncoated base engine and uncoated increased life engine $=1455^{\circ} \mathrm{K}\left(2160^{\circ} \mathrm{F}\right)$.

\title{
3.2 UNCOATED PERFORMANCE
}

\subsubsection{Base Engine Simple Cycle}

The FT50A-4 was chosen as the base from which the thermal barrier coating performance effects would be calculated. The cycle characteristics of this reference engine with $1144 \mathrm{~K}$ $\left(1600^{\circ} \mathrm{F}\right)$ turbine airfoil maximum metal iemperature are illustrated in Figure 3-1. However, since the turbine life of the base engin: is limited by hot corrosion to 10000 hours, an increased life uncoated engine was defined to operate at $1088 \mathrm{~K}\left(1500^{\circ} \mathrm{F}\right)$ turbine airfoil maximum metal temperatures and its cycle charanteristics are also presented in Figure 3-1. This second uncouted design has at least 30,000 hours life. The turbine airfoil cooling flows for each of thesc engines are shown on Table 3-11. 

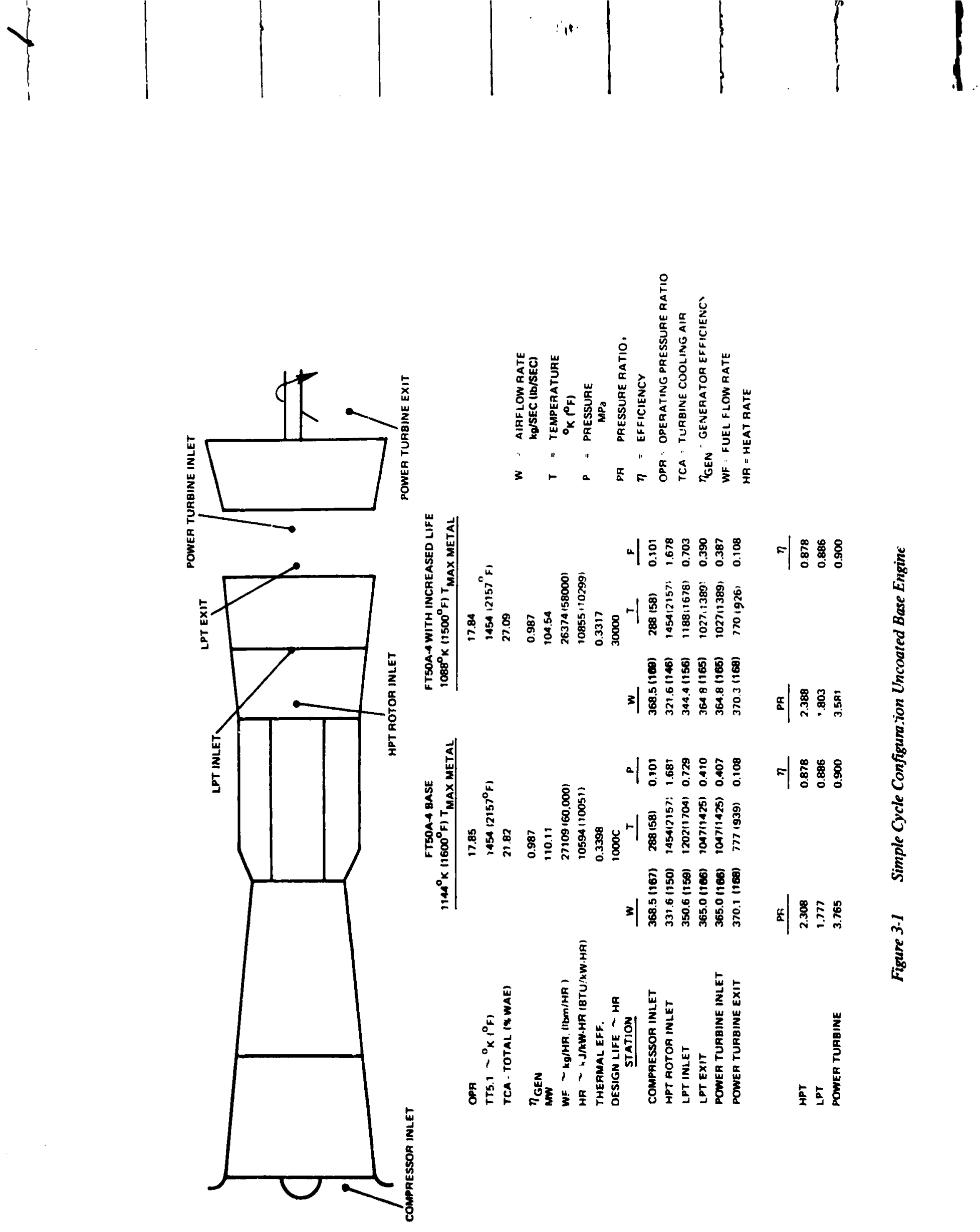


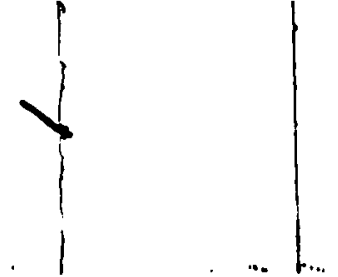

|AB|.: 3 แ|

IURBINI: AIKIOHL. C(X)I.INC; JLLWS

\begin{tabular}{|c|c|c|c|c|}
\hline Source & Descriptioth. & $\begin{array}{l}\text { Fis0A.4 } \\
T_{\text {max metal }}=1088^{\circ} \mathrm{K}\left(1500^{\circ} \mathrm{F}\right) \\
T_{\text {rutur }}=1455^{\circ} \mathrm{K}\left(2160^{\circ} \mathrm{F}\right) \\
\left(\text { (K } \mathrm{W}_{A F}\right)\end{array}$ & 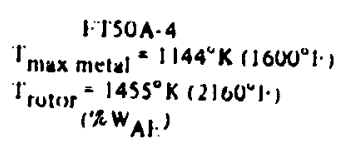 & 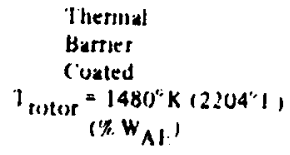 \\
\hline Station 4.0 & Ist Vane & 10.5 & xo & $4 t s$ \\
\hline Station 4.0 & Ist Hiaje & 413 & 3.10 & $1 . x 2$ \\
\hline 1 & 2nd Vane & 2.70 & 197 & 110 \\
\hline \multirow[t]{2}{*}{13 th Stage } & 2nd Hiade & 1.11 & 50 & 805 \\
\hline & $\begin{array}{l}\text { Total Turbine } \\
\text { Cooling Ar }\end{array}$ & 27.04 & 21.82 & $\mid 6.01$ \\
\hline
\end{tabular}

\subsubsection{Base Engine Combined Cycle}

The steam bottoming cycle foi the base engine and the increased life uncoated engine were defined using the following groundrules:

1. Steam turbine exit quality was held at 0.9 to provide maximum power output with acceptable steam turbine life.

2. Pinch points for the superheater, high pressure boiler, low pressure boiler, and deaerato: were held at $283 \mathrm{~K}\left(50^{\circ} \mathrm{F}\right)$ to provide practically sized heat exchangers.

3. Gas Turbine exhaust stack temperature was held at $422 \mathrm{~K}\left(300^{\circ} \mathrm{F}\right)$ to prevent condensation of sulfuric acid in the stack.

To satisfy these groundrules, a two pressure steam bottoming cycle was selected. The steam flow and boiler pressures were optimized to provide the lowest heat rate. Figures 3-2 and 3-3 show schematics of the steam systems including pressures, temperatures, and steam flows for the base engine and the increased life uncoated engine configurations, respectively. 


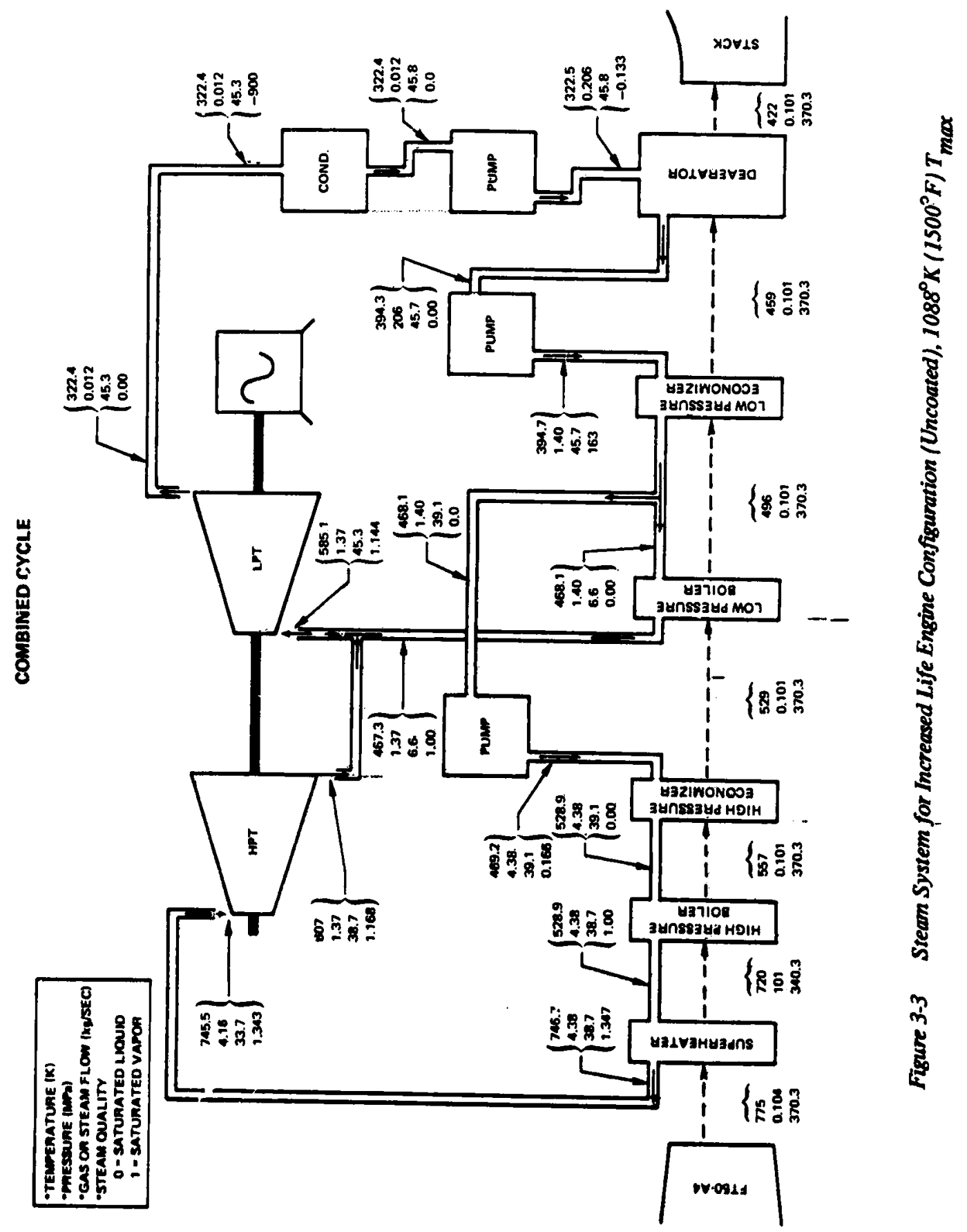




\subsection{THERMAL BARRIER COATED PERFORMANCE}

\subsubsection{Thermal Barrier Coating Simple Cycle}

Application of the thermal harrier coating to the turbine airfoils could result in (1) reductions in cooling flow required to maintain a given metal temperature, $(2)$ increased turbine gas temperatures-at a given cooling flow rate and turbine metal temperature, or (3) a combination of decreased cooling flow and increased gas temperisture to provide the lowest heat rate. Figure 3-4 illustrates the performance effects of a variation in cooling flows and turbine gas temperature to maintain $1088 \mathrm{~K}\left(1500^{\circ} \mathrm{F}\right)$ and $1144 \mathrm{~K}\left(1600^{\circ} \mathrm{F}\right)$ maximum metal temperatures-and to maintain a constant 30.000 hour turbine life. The figure indicates that increased gas temperature and increased metal temperature reduce the heat rate until reaching the power turbine constraint. The uncooled power turbine does not benefit from the use of thermal-barrier coatings and is therefore limited to.a $1088^{\circ} \mathrm{K}$ inlet temperature to meet the 30,000 hour life criteria.
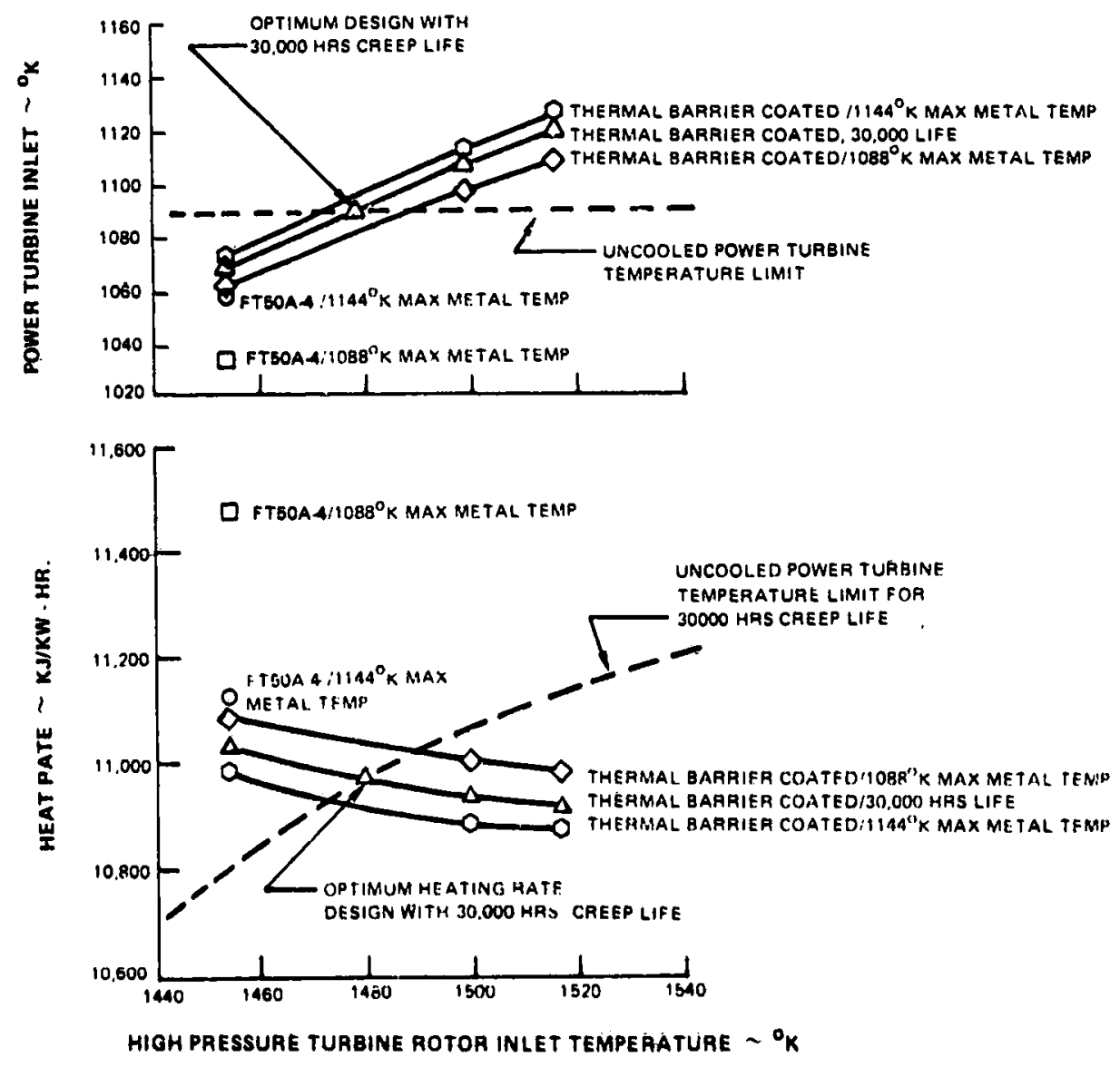

Figure 3-4 Performance Optimization

Of the three thermal barrier coated turbines, the 30.000 hour turbine was chosen over the $1144^{\circ} \mathrm{K}\left(1600^{\circ} \mathrm{F}\right)$ maximum metal temperature turbine because it met the turbine life criteria, and the $1088^{\circ} \mathrm{K}\left(1500^{\circ} \mathrm{F}\right)$ maximum tempernture turbine because of a better lieat rate. The gas turbine pressures, temperatures and airflows for the selected thermal barrier coated engine are illustrated on Figure 3-5. 


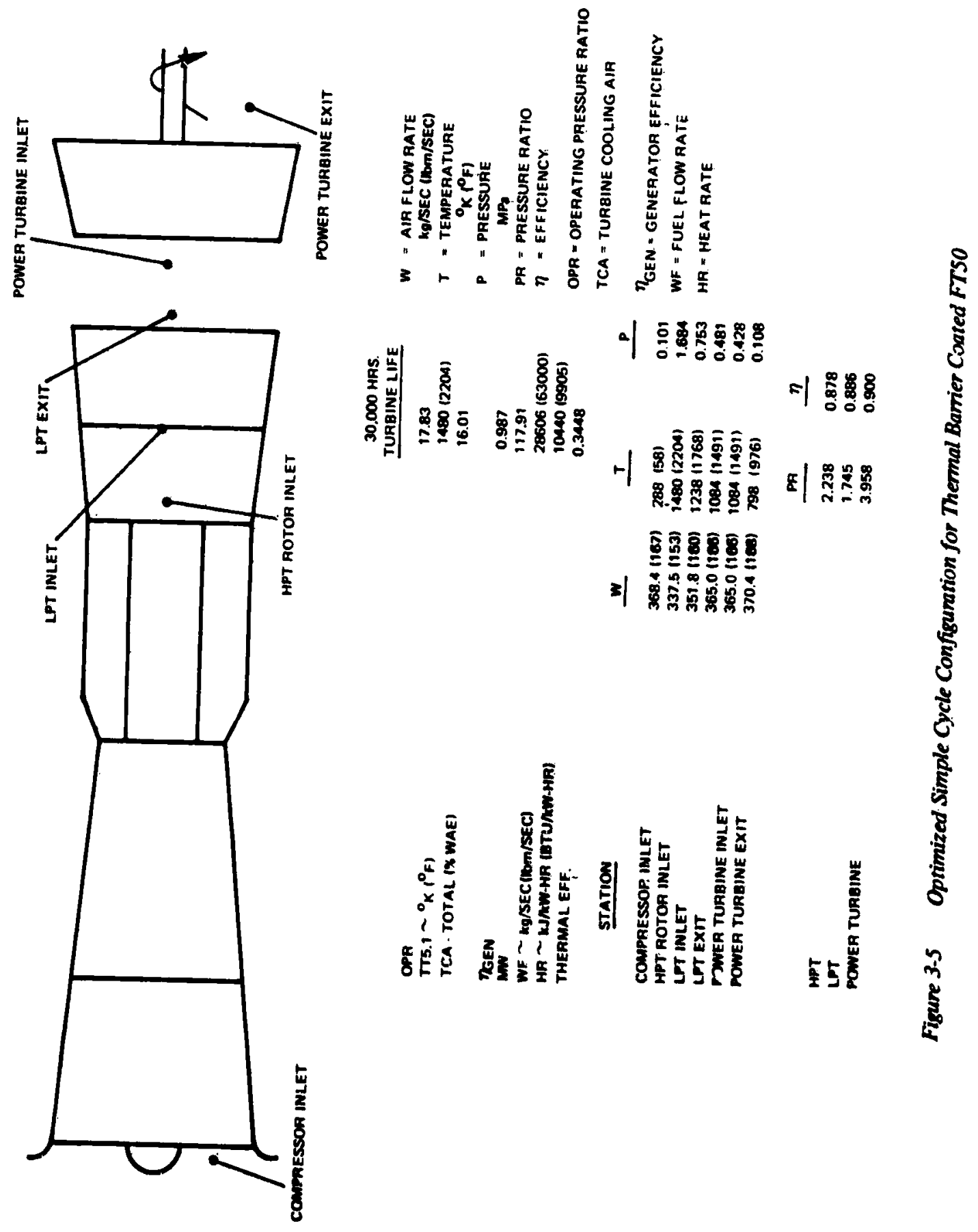


The turbine cooling flows used to calculate the optimized thermal barrier coated engine performance are shown on Table 2-II in the turbine analysis section (Section 2.0). The reduced flow requirements were calculated for Inco 738 blade material and AMS 5382 vane material which are the same materials used in the base engine. Although further reduced cooling flow requirements are possible with an increased strength material, a perforamnce analysis was not made because the performance benefit of the thermal barrier coating was sought without other benefits that could be incorporated in an uncoated engine.

Table 3-III shows the power (MW), fuel tlow (WF), heat rate (HR) and thermal efficiency ( $\eta \mathrm{TH})$ of the thermal barrier coated turbine with residual ("dirty") and distillate ("clean") fuels for the $1088^{\circ} \mathrm{K}\left(1500^{\circ} \mathrm{F}\right)$ and $1144^{\circ} \mathrm{K}\left(1600^{\circ} \mathrm{F}\right)$ metal temperature turbines as well as the 30,000 hour turbine. All engines are shown in both the simple cycle and combined cycle configurations. The performance difference between residual $(42990 \mathrm{~kJ} / \mathrm{kg}(18500$ $\mathrm{Btu} / \mathrm{lbm}) \mathrm{HHV}$ ) and distillate $(44960 \mathrm{~kJ} / \mathrm{kg}(19350 \mathrm{Btu} / \mathrm{lbm}) \mathrm{HHV})$ fuel was very small and resulted from the difference in mass flow required to provide the same heat. No derating of turbine inlet temperature was assumed when using the residual fuel. The performance improvement for the thermal barrier coated turbine and burner were the result of decreased cooling flow and vane pressure loss, and increased turbine rotor inlet temperature.

\subsubsection{Thermal Barrier Coated Combined Cycle}

The steam bottoming cycle for the optimized thermal barrier coated engine was designed to satisfy the same groundrules as the base engines steam cycles. Because of the increased power turbine discharge temperature of the thermal barticr coated engine, the steam cycle operated at higher temperatures and pressures increasing the steam cycle power output and efficiency. Figure 3.6 illustrates the pressures, temperature and steam flows of the steam bottoming cycle used with the thermal barrier coated engine. 

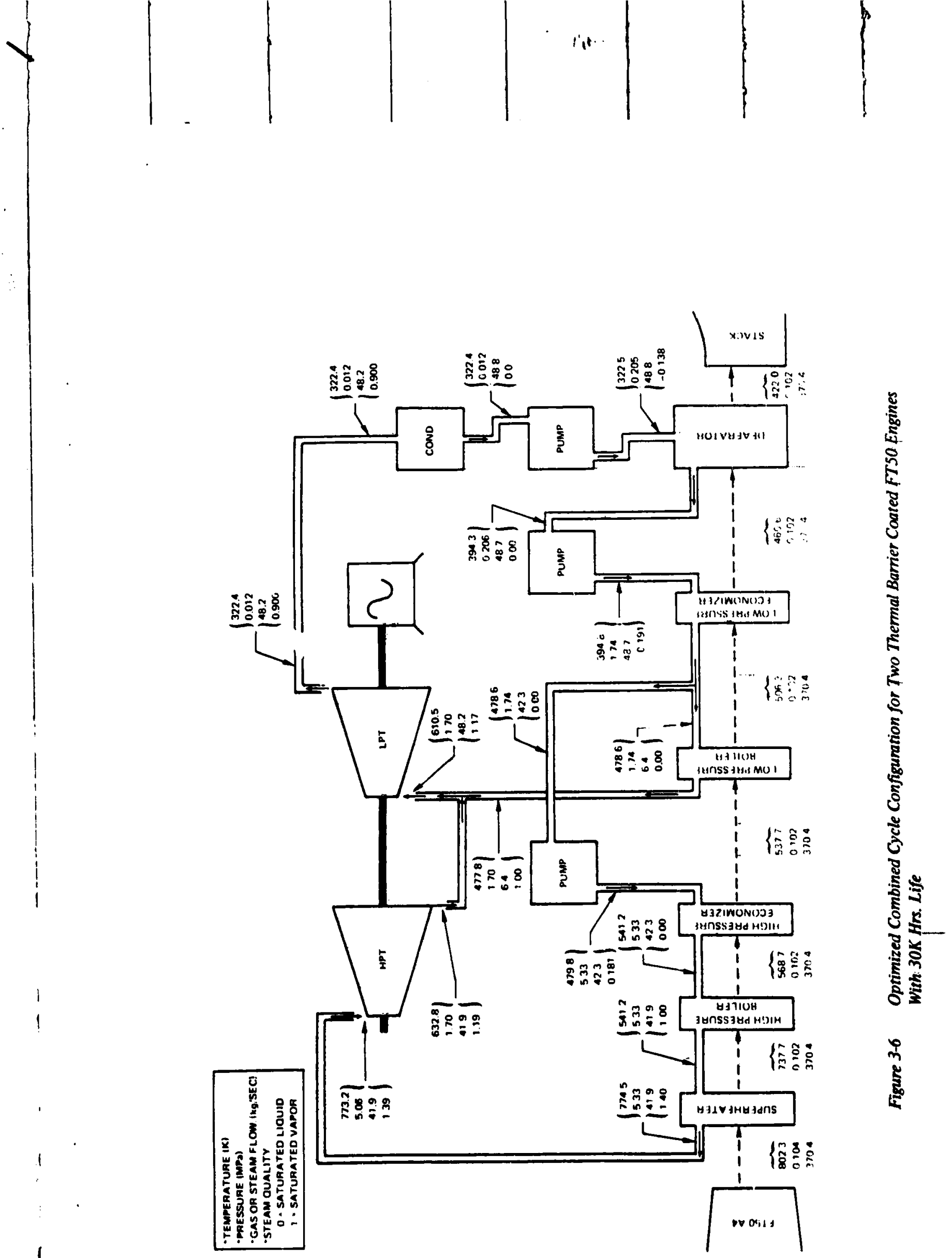


\subsection{COST IMPACT ASSESSMENT}

This section contains the assumptions used in the cost analyses and the results of the cost impact assessment. Both capital and operating costs are expressed in mid-1976 dollars. No escalation or interest has-been included because both depend on start date and construction period: however, cost estimates are presented in sufficient detail to allow one familiar with power plant economics to readily adjust the values to any future period. The capital cost values presented are budgetary-type estimates and.are not an offer on the part of United Technologies Corporation to commit to a firm contract for equipment.

\subsection{CAPITAL COST ASSUMPTIONS}

\subsubsection{Simple-Cycle System}

The simple-cycle station consists of a single FT50-type engine, all associated equipment needed to generate power, transformer equipment for $230 \mathrm{kV} .60$-cycle output power, one fuel storage tank, a fuel containment dike, land and all necessary site equipment, including the peripheral fencing. The power generation site is assumed to be located near an Fast Coast commercial/industrial area where the land, estimated at $\$ 100,000$ per acre, is adjacent to a rail siding. The entire unit is self-contained except for remote computer controls and monitoring equipment which permit unattended operation. The site areal contains the gas turbine-generator building (approximately 0.6 acres), a square dike (capable of containing a spill of the entire fuel tank at a depth not to exceed three fect), a pump house and switchyard. The average simple-cycle site size is five acres -

The basic gas turbines with their associated equipment, as noted in Table 4-1, include foundations and, in the case of the residual-fueled units, a fuel treatment system. Whereas a complete breakdown of individual equipment capital costs was developed, on!y the composite value is presented in order to protect the proprietary nature of the individual components, and particularly that of the gas turbine. Two fuels, a clean distillate $(141,800 \mathrm{Btu} /$ gallon) and a residualstype (150,000 Btu/gallon) were considered, and then were used alung with the performance estimates to size the tank farm. The tank capacity was based on a 30-day storage capacity at a load factor.of 0.45 .

The additional equipment capitalized during construction was estimated at three percent of the construction cost (material, equipment and installation labor), and the system was assumed to be designed and constructed by a typical A\&E (Architectural and Engineering) firm who would add to the total direct construction cost a $10 \%$ allowance for contingency and $15 \%$ allowance for engineering services and construction supervision. All profit allowances are included in the estimates of the individual line items. The bottom line (specific capital cost) is the sum of all category entries divided by the net plant output. 


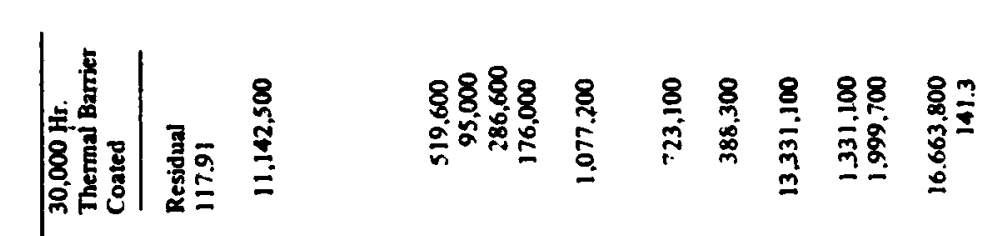

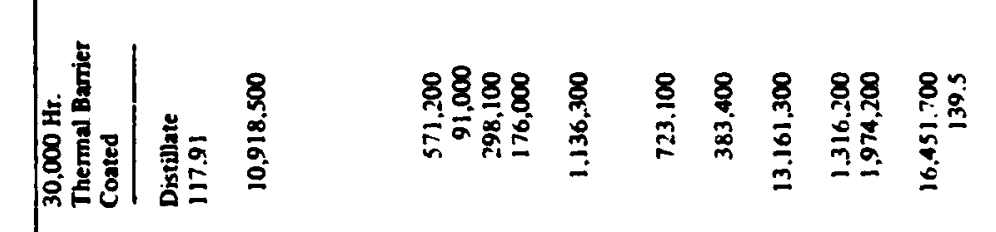

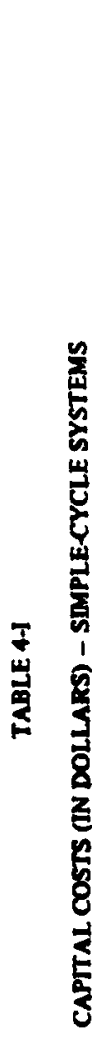

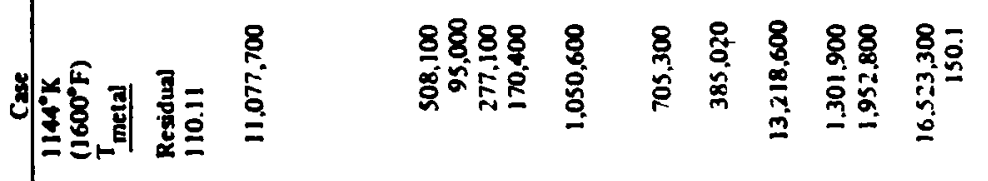

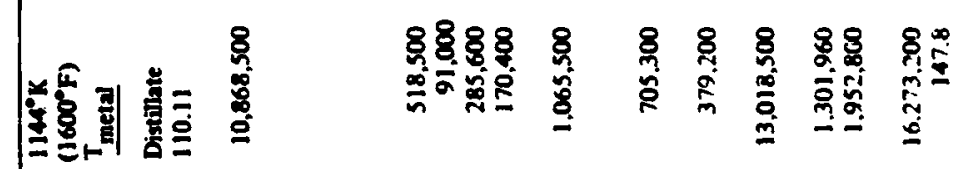

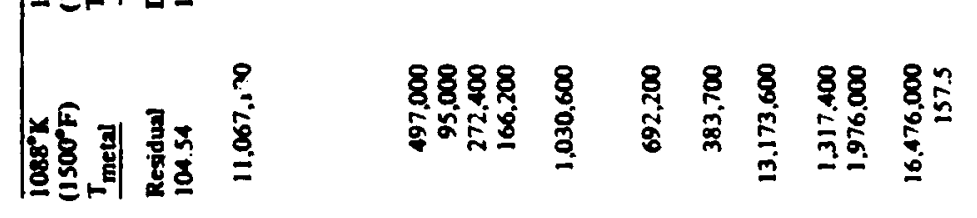

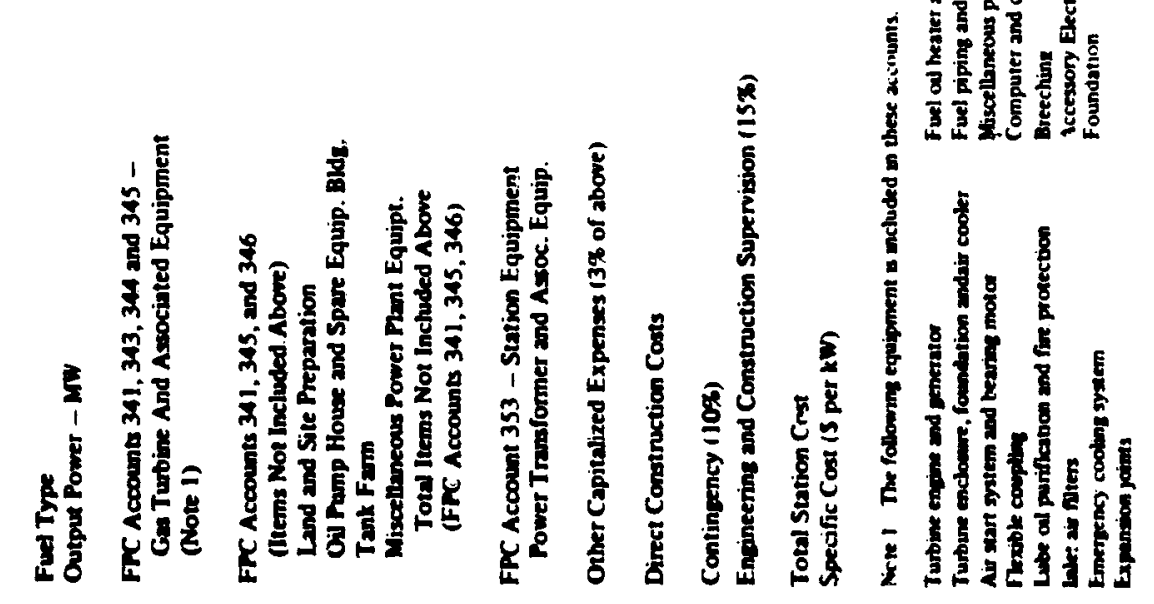




\subsubsection{Combined-Cycle System}

The combined-cycle system.consists of two 1-T50-type gas turbine engines, a single twopressure steam turbine, and associated electrical and mechanical equipment. The system output is nominally $300 \mathrm{MW}$.depending upon the operating conditions, as noted in the performance section of this report. This station.is assumed to be located at the typical Middletown. USA location where land is valued at $\$ 1000$ per acre. The combined-cycle system is to be self-contained, including the administration building, repair and storage facilities. at rail siding, and the fuel storage tank farm. Fach of the basic turbines in the combined-cycle system, incorporates the same set of equipmentuat essentially the same cost as that noted for the simple-cycle system.

The heat encrgy in the gas turbine exhausts is transferred to the steam system in al single unfired, dual-flow, waste-heat hoiler divided by means of a baffle down its centerline. In this manner, no intermixing of engine exhaust gases in this boiler are allowed, thereby alleviating backflow problems when only one gas turbine is operating. The single, twopressure steam turbine is connected to its own generator, the power from which, as well as that from the gas-turbine-driven generators, is transformed to a line voltage of $500 \mathrm{kV}$ at 60 cycles. Stium turbine waste heat is rejected through a w't, mechanical draft cooling tower, whereas the combined exhaust flow of the gas turbines is directed up a single, $45.7 \mathrm{~m}$ (150 ft) stack after exiting the waste heat boiler.

Only residual fuel with a heating value of 150,000 Btu per gallon was considered for the combined-cycle stations. Fuel storage on-site was considered adequate for a 60 -day period at a load factor of 0.65 (enough for approximately 936 hours of operation). Two cylindrical fuel storage tanks with conical roofs were assumed, and the surrounding rectangular dike area was sized to contain the simultaneous spill of both tanks to a height not exceeding three feet. Including the tank farm, 50 acres were allowed for each combined-cycle site.

The additional equipment capitalized during construction was estimated at three percent of the sum of all equipment, materials and construction labor. This system was also assumed to be designed and constructed by a typical A\&t: firm who would add to the total direct construction cost an additional 15\% allowance for contingency and 20\% for engineering and
construction supervision services. All profit allowances have been included in the individual line items. It should be noted that the basic cost correlations, for which both the simplecycle and combined-cycle economic estimates have been made, refer to an East-Coast site. Consequently, it was necessary to make an adjustment to the combined-cycle system estimates to reflect Middletown, USA construction costs. This was accomplished by utilizing a procedure from an unpublished EPA. report. This procedure makes adjustments primarily on the basis of different labor rates, since inaterials and equipment do not vary with site location. As a result, the estimates for the Middletown, USA site are not presented on a line-item basis, but rather only on a total construction cost basis, excluding escalation and interest. Because of the detail used in developing the basic East Coast estimates, it is believed these Middletown, USA site estimates have a high degree of reliability. 


\subsection{OPERATING COST ASSUMPTIONS}

This section contains the assumptions associated with developing the power station production cost analysis for both the uncoated and the thermal barrier coated FT50 marthines operating in the simple-cycle and combined-cycle modes. For both types of systems, a capital recovery factor of 0.18 was used which incorporates not only utility profit, but also depreciation insurance, taxes, and all other fixed station cost charges. The load factors considered for the simple-cycle system are 12 percent and 45 percent ( 1050 hours and 3940 hours, respectively ); whereas, the load factors for the combined-cycle system are 45 percent and 65 percent ( 3940 hours and 5700 hours, respectively).

The fuel charges are directly proportional to the heat rates of the respective systems as noted in the section presenting system performance. The residual fuel was assumed to cost $\$ 2.15$ per million Btu's, and, the distillate fuel, when available, was assumed to cost $\$ 2.60 \mathrm{p} \cdot \mathrm{r}$ million Btu's. The following assumptions were made with respect to operating and maintenance charges. For all systems, the basic operating and maintenance charge of 2.0 mils per $\mathrm{kW}$-hr was assumed to cover all (steam and gas turbine) system costs except those for the hot parts in the gas turbine; these latter parts were considered separately. In addition. a charge of $30.0 \mathrm{mils} / \mathrm{million}$ Btu's was added for fuel additives in residual fuels. In the systems containing the gas turbines limited to a maximum metal temperature of $1088^{\circ} \mathrm{K}$ $\left(1500^{\circ} \mathrm{F}\right)$, all hot parts (bumer, transition duct, blades and vanes in high and low turbines) were assumed to have a 30,000 hour life. However, refurbishment of these parts was necessary after 10000 and 20000 hours of operation. United Technologies Corporation refurbishment costs were used while tear-down and rebuild labor was based on United Technologies Corporation time estimates and a total utility burdened man-hour rate of $\$ 20$ per hour. For the $1144^{\circ} \mathrm{K}\left(1600^{\circ} \mathrm{F}\right)$ maximum allowable metal temperature gas turbine cases; it is necessary to replace the turbine parts after 10,000 and 20,000 hours of operation although the bumer and transition duct still have a 30,000 hour life. In addition, the blades and vanes must be refurbished at 3300 hour intervals, while the bumer parts inust be refurbished at $\mathbf{5 0 0 0}$ hour intervals. Refurbishment charges and replacement part costs are based on United Technologies Corporation rates while tear-down and rebuild charges were assurned at utility rates, as above. For the thermal barrier coated cases. all parts are assumined to last 30,000 hours although recoatings were considered parametrically for intervals of 5000 hours, 10,000 hours, and 15,000 hours. Recoating costs and labor charges are based on UTC rates as in the previous cases. The respective engine coating/refurbishmerit charges were added to the base 2.0 mils per $\mathrm{kW} / \mathrm{hr}$ estimates and the fuel additive charge (when necessary) to determine total operating and maintenance charges. These were then added to the respective capital and fuel charges to determine the overall power production cost expressed in mils per $\mathrm{kW} / \mathrm{hr}$.

Although these power production charges are presented in terms of mid-1976 dollar values, sufficient detail is presented to allow the reader to make other adjustments based on different assumptions. Whereas the absolute level of these charges may vary, depending on time of construction, site selection, and economic conditions, it is believed that the relative charges, and in particular the incremental changes due to thermal barrier coatings, should not change. It is these incremental values which are of particular interest in defermining the overall benefits to be derived from adapting such technical innovation. 
ORIGINAL PAGE IS

OF POOR QUALIIY

TABLE A-II

(APITAL COSTS (IN DULLARS) CUMBINFUCYCIII SYSTEMS

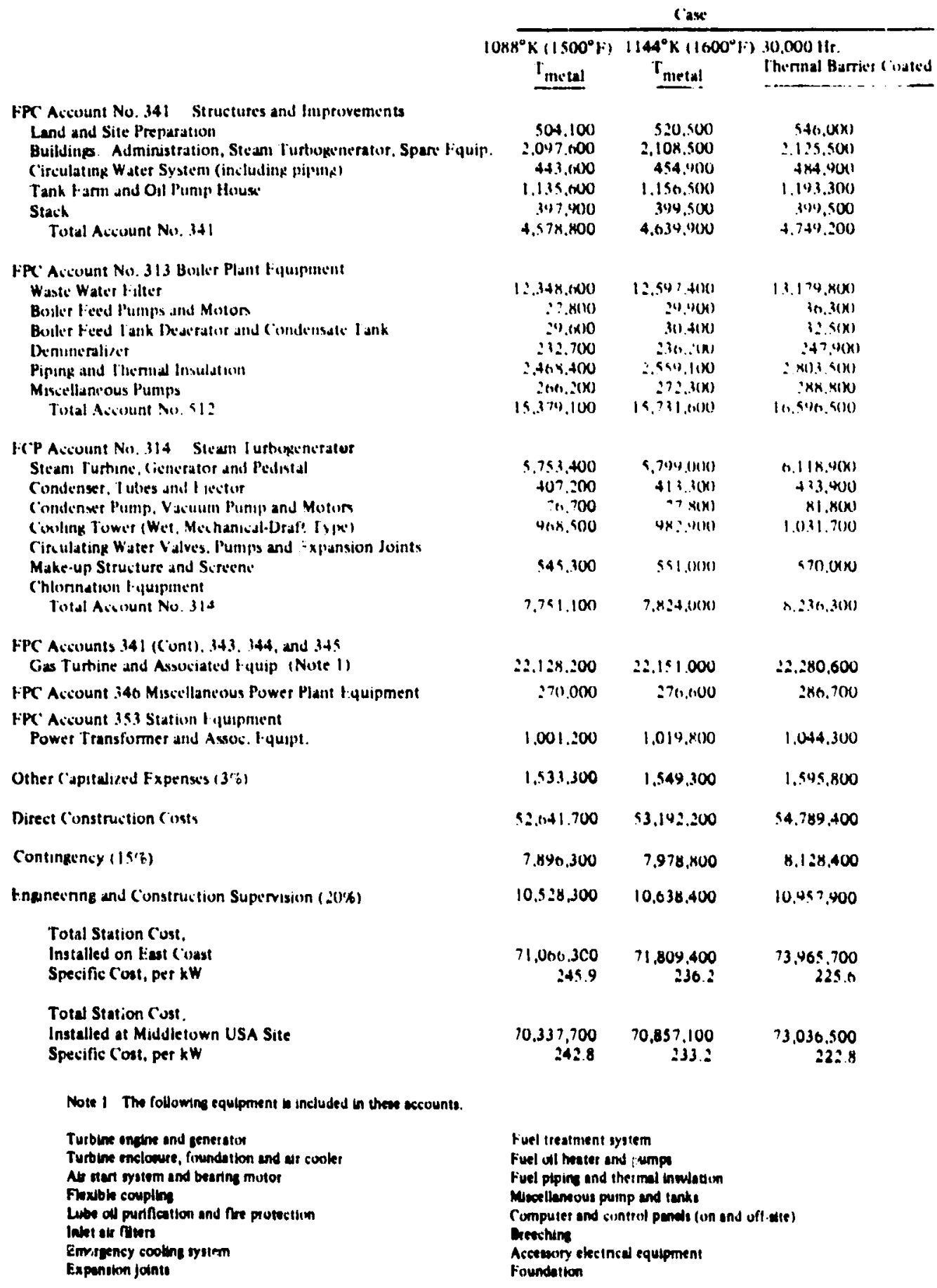


$y$

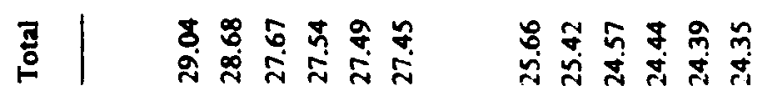

¿

|

言| \&

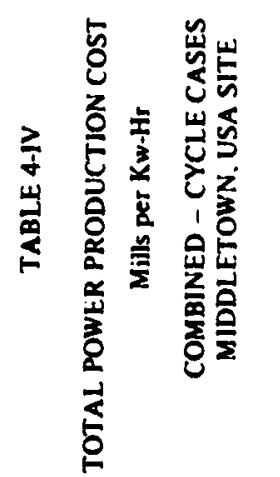

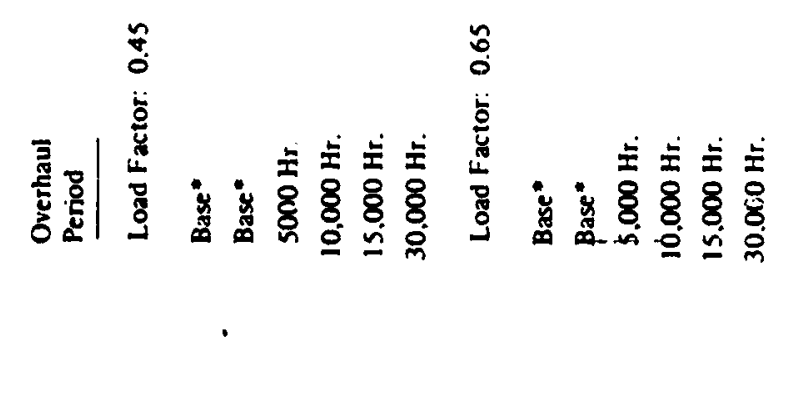

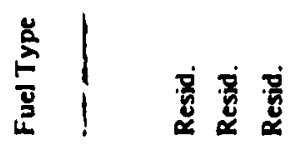

15n

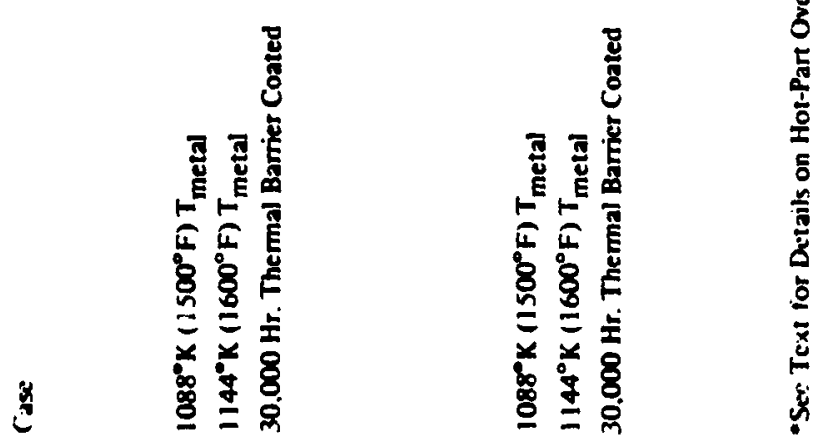


considered. Although the operating and maintenance charge on the steam portion of the combined-cycle systems likely will be less than that for the gas turbine portion of these systems, the conservative estimate-of 2.0 mill per $\mathrm{kW}$-hr $\mathrm{h}$ as an insignificant effect on the overall power costs.

It is noted that because of the lower assumed cost. of residual.fuel.relative to that assumed for the distillate fuel, and the fact that the heat rates of the engines. with these respective fuels differ only slightly, the residual fueled systems are estimated to produce the lowest cost power.

Upon examining the differences in fuel savings attributable to the use of themal barrier coatings in the gas turbine, the following important observations can be made. The savings in fuel between that of the simple-cycle engine with a maximum metal temperature of $1088^{\circ} \mathrm{K}(1500 \mathrm{~F})$ and that of the thermal barrier coated engine amounts to nearly $\$ 3.5$ million, from a savings of nearly 200,000 barrels of oil when compared-on an equal total electric energy production basis. (The total electric energy produced with the $1088^{\circ} \mathrm{K}$ $\left(1500^{\circ} \mathrm{F}\right)$ maximum metal temperature simple-cycle engine over its 30,000 hour life can be produced with the thermal barrier coated engine in 26,600 hours, with both engines using residual fuel.) Between the simple-cycle engine designed for a maximum metal temperature of $1144^{\circ} \mathrm{K}\left(1600^{\circ} \tilde{\mathrm{F}}\right)$ and the thermal bartier coated engine, the benefit is less, but is still respectable, amounting to over $\$ 1.3$ million from a savings of 77,000 barrels of oil on an equal total energy production basis. For the combined-cycle systems, larger savings per two-engine installation are predicted. On the same basis as above, a comparison between the base engine operation at $1088^{\circ} \mathrm{K}(1500 \mathrm{~F})$ maximum metal temperature and the thermal barrier coated engine conditions reveals that the combined-cycle system would be expected to provide a cost savings of over $\$ 5$ million, the equivalent of 409,000 barrels of oil. Between the maximum metai temperature of $1144^{\circ} \mathrm{K}(1600 \mathrm{~F})$ condition and the cuated case, the expected savings over the engine life would be approximately $\$ 3$ million, or the equivalent of 229,000 barrels of oil per two-engine unit, again compared on a total energy basis. These forecast savings show that improved performance with thermal barrier coating more than makes up for any incremental costs of increased operating and maintenance charges due to the coatings. Furthermore the savings from only a few engines should more-than pay for any costs associated with the coating development program.

\subsection{CONCLUSIONS OF ECONOMIC STUDY}

From an economic standpoint, the use of thermal barrier coatings in an advanced FT50-type engine is predicted to result in a power reduction cost of $3-6 \%$ for the simple-cycle and $3.5 \%$ for the combined cycle relative to an uncoated engine design. In addition, an incentive to use this concept is provided by the fact that over the engine operating life, a considerable amount of oil can be conserved while still meeting a given level of consumer power demand. The results are presented in terms of mid-1976 dollar values. An increase in system cost (due to escalativi: and the need to charge for interest during construction) as well as any increase in fuel charge would serve to improve attractiveness of the system. Whereas the operating cost estimates of these systems are based on the best possible equipment cost correlations, no allowance has been made for on site power consumption. Relative to the cost of the total cost of energy, however these costs would likely comprise less than $2 \%$ of the total power production cost and, therefore, would not bave a significant effect on the results presented herein. 


\subsection{DEVELOPMENT PLAN FOR THERMAL BARRIER COATINGS}

\subsection{PROGRAM OVERVIEW}

A development program has been devised for thermal barrier coatings aimed at conducting the significant research and technology activities necessary to achieve a.commercial demonstration in a high temperature industrial gas turbine engine. The plan shown in Figure 5-1 has four phases. These are Current Data Bank, Coating Technology Development, Design Support Technology, and Engine Demonstration Programs. The first phase,.described as the Current Data Bank, involves taking advantage of in-house experimental and production engine combustor coating development activities and experience. The current thermal barricr coated combustor components now in production and accumulating field experience are listed in Figure 5-2. Also included in the Current Data Bank is United Technologies Corporation (UTC) internal research and development work to apply thermal barrier coatings to turbine components. These activities, which are UTC tunded, provide a substantial technical base on which significant additional research and technology activities directed toward achieving a commercial engine demonstration of thermal barrier coatings can be developed.

The major research and technology activities are described in the second phase titled Coating Technology Development. Three technology areas are identified: these are Process Technology, Durability Technology, and Erosion-Corrosion Technology. The objectives for the Process Technology Plan, shown in Figure 5-3, are to develop a temperature controlled arc plasma spray process to increase coating life by reducing coating residual thermal st ress levels. and to develop coating application techniques for cooled turbine components. The Durability Technology Plan, shown-in Figure 5-4, is aimed at testing the best coating process on turbine and combustor components in a thermal mechanical fatigue environment. The purpose of the Erosion-Corrosion Technology Plan is to evaluate and develop the coatings resistance levels to an erosive-corrosive environment. The Erosion-Corrosion Technology Plan is shown in Figure 5-5.

The third phase, described. as New Design Support Technology, involves thermal barrier coating material design properties and design tools development. Material properties for design use are categorized as thermal or mechanical properties and detailed in Figure 5-6. Design tools development includes computer program modifications and the development of a coating life prediction system. The computer program modifications are planned as part of P\&WA internal research and development activities not to be charged to contract.

The fourth phase, Engine Programs, is the final phase of activity to demonstrate the use of thermal barrier coatings on hot section components in a high temperature gas turbine engine.

The following sections pruvide supporting information for-the tectinical programs of Phases II and III, and a general discussion of Phase IV. Phase $l$ is not specifically an item to be fun. ded under this plan but rather is an on-going UTC supported effort that will provide inputs to help guide this development in an efficient, cost effective manner. 


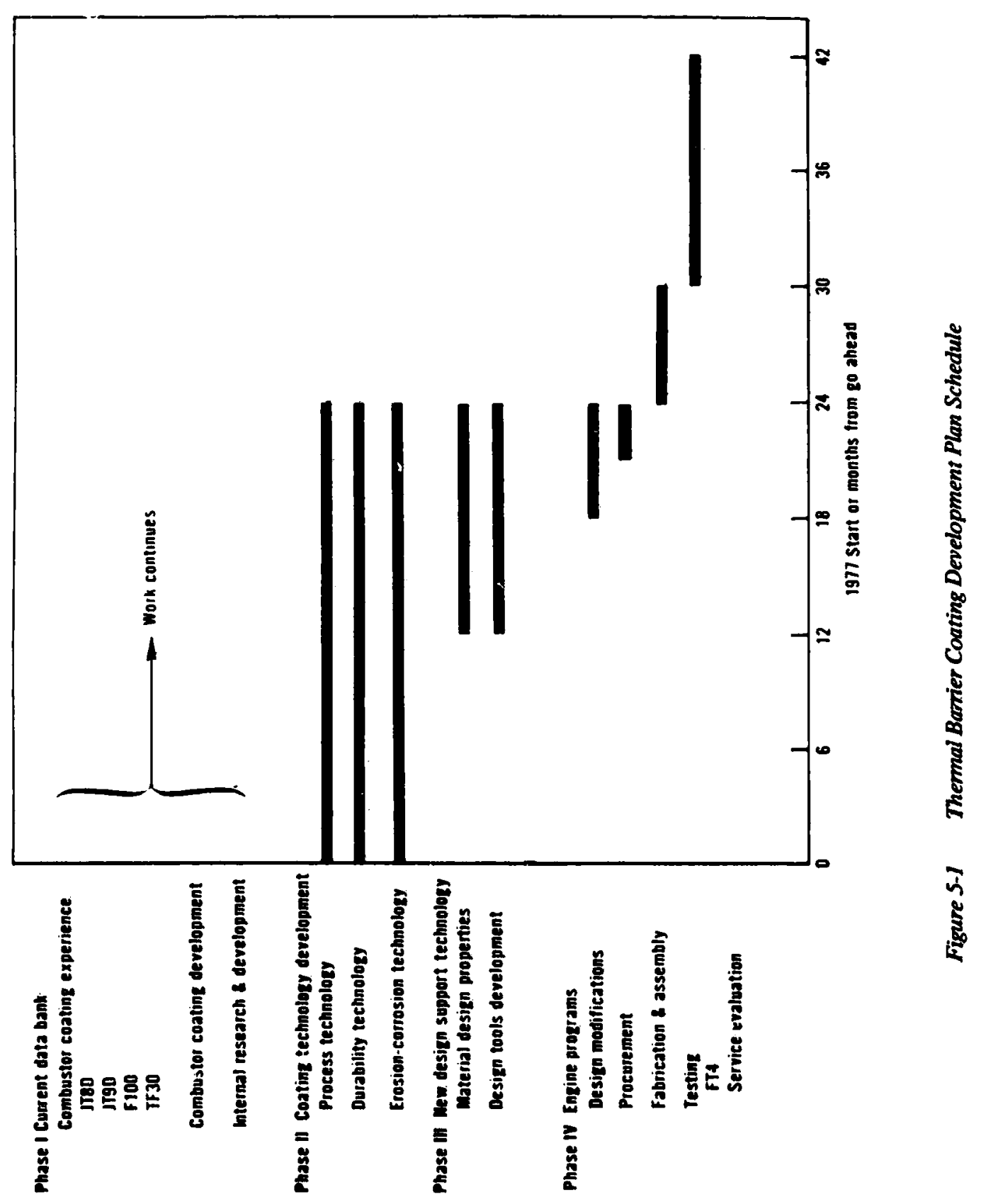




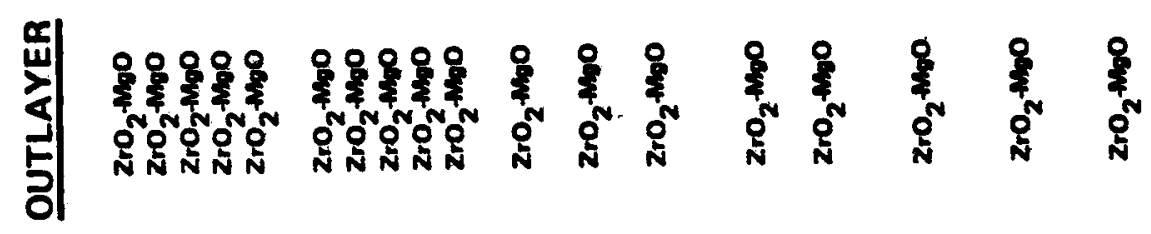

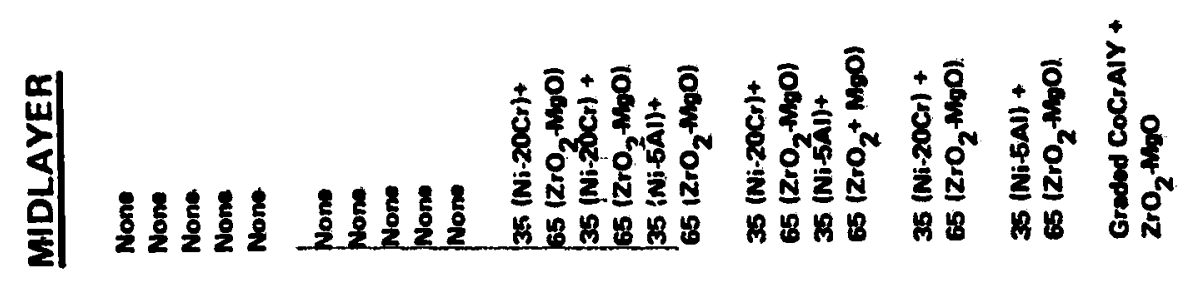

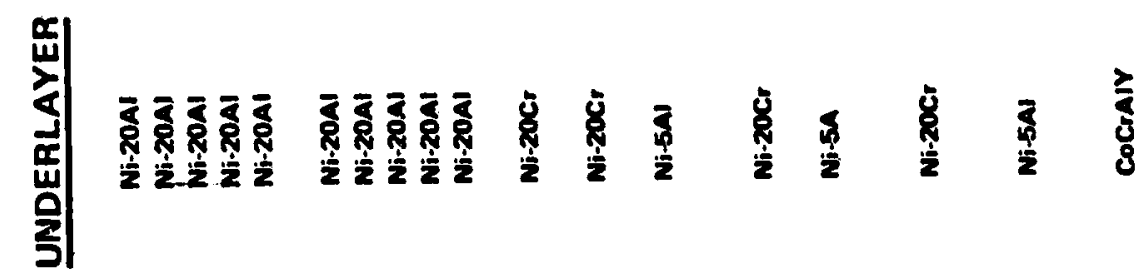

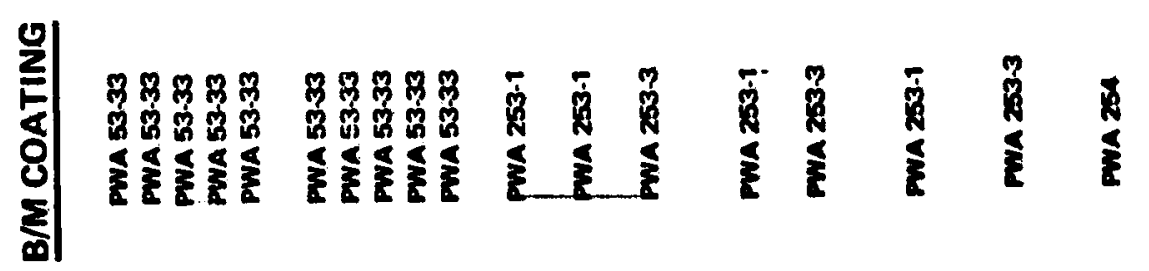

thll|l|l|11।

亩界,

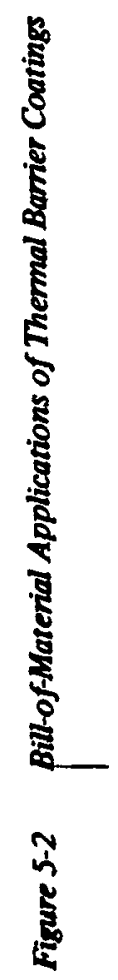


1.1 Proparation

Spiay apparatus instrumentation

iselup

Procure tost specimans

flat.

Curved

Specimen instrumentation

1.2 Caating application

Two compositions A \& 8

Temporature/stiess control

Flat specimens. -

Reom temp

Clevated temps

Curved specimens

Room temp

Elovated temps

1.3 Life evaluation .

Thermal fatigue losis

Flat specimens

Curved specimens

Analysis of processies and

composition testine

1.4 Application techiniques

Autemated component application Thiskness control

Messutement apnaratus

less than 15 mils

Grecter than 15 mils

Automated spray apparatus dev

Cemposition uniformity

Size

Small (conventional turbines] lare (FT50 type turbines)

Shape

Airfoils

Platlorms

Surface condition

Spray vafiations

Powder variations

Post lost mochanical method

Post lest mechenical mothod 2 High velocity gun affects

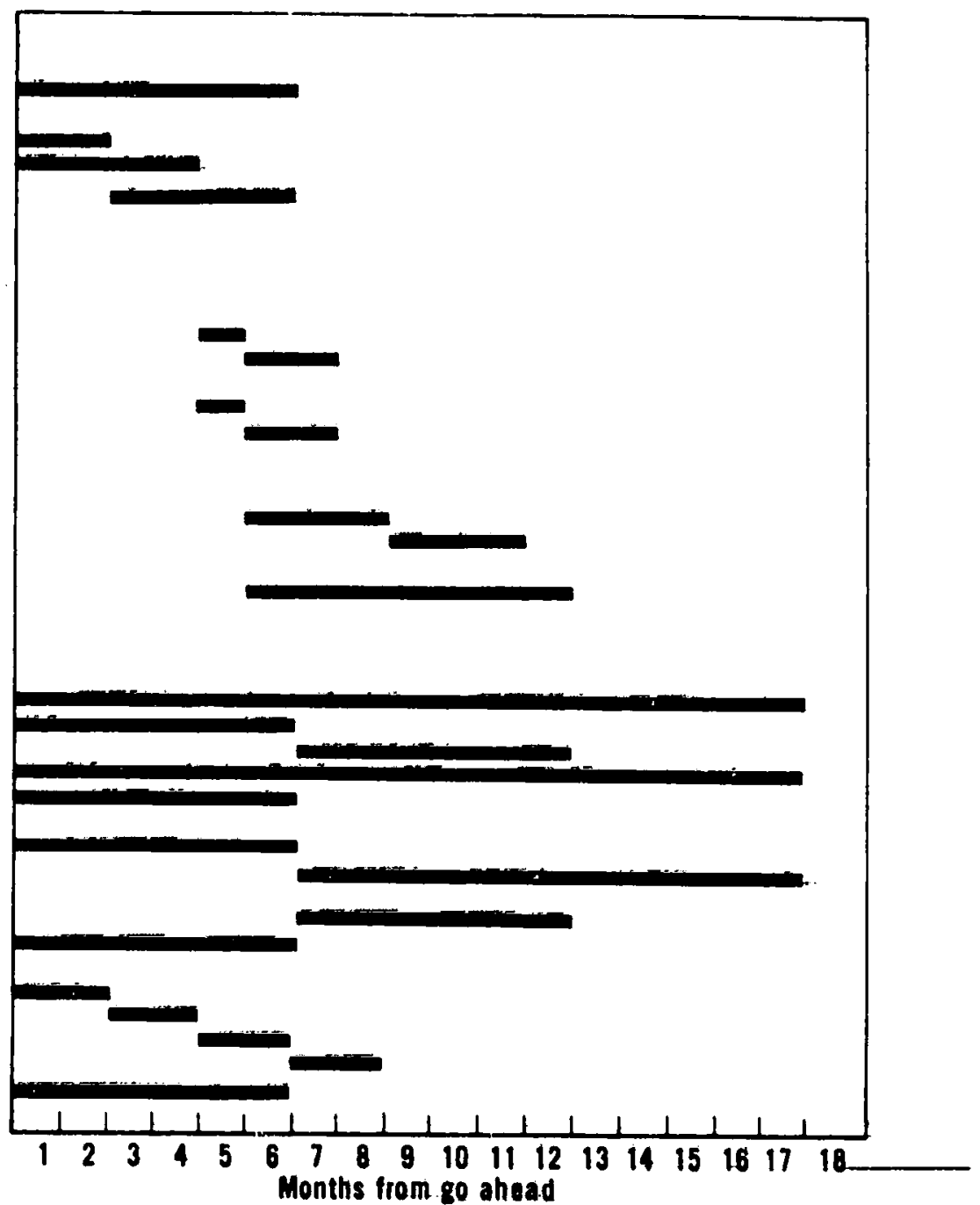

Figure 5.3 Phase I/ Coating Technology Development, Task I Process Technology 

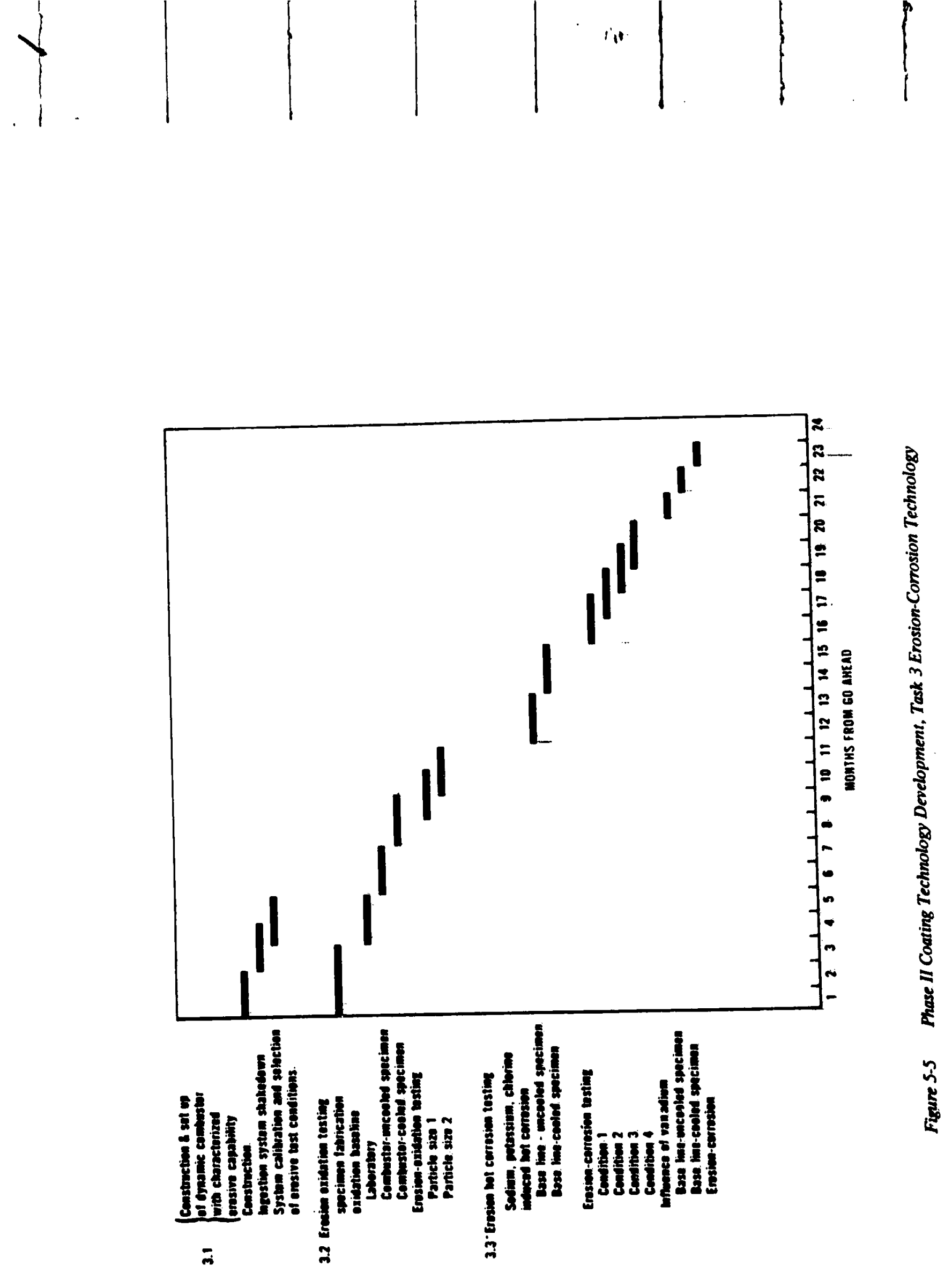


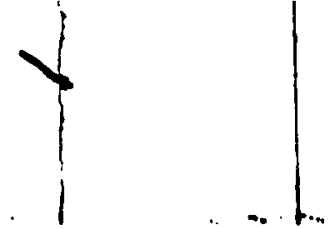

\subsection{PHASE II - COATING TECHNOLOGY DEVELOPMENT}

Coating Technology Development is composed of three significant technology tasks. These are Coating Process. Technology, Coating Durability Technology, and Coating Erosion and Corrosion Technology.

\subsubsection{Coating Process Technology}

The major objectives of the Coating Process Technology are to develop thermal stress control and application techniques for improved coating durability. Arc plasma spray processes now in use for combustor applications are automatically controlled to meet production specifications. The elements of the plasma spray process are shown in figure 5-7. Coatings on turbine components are generally manually applied and therefore are highly dependent on operator technique. Coating stresses induced during the depositing of coating materia! are also believed to be operator and process dependent.

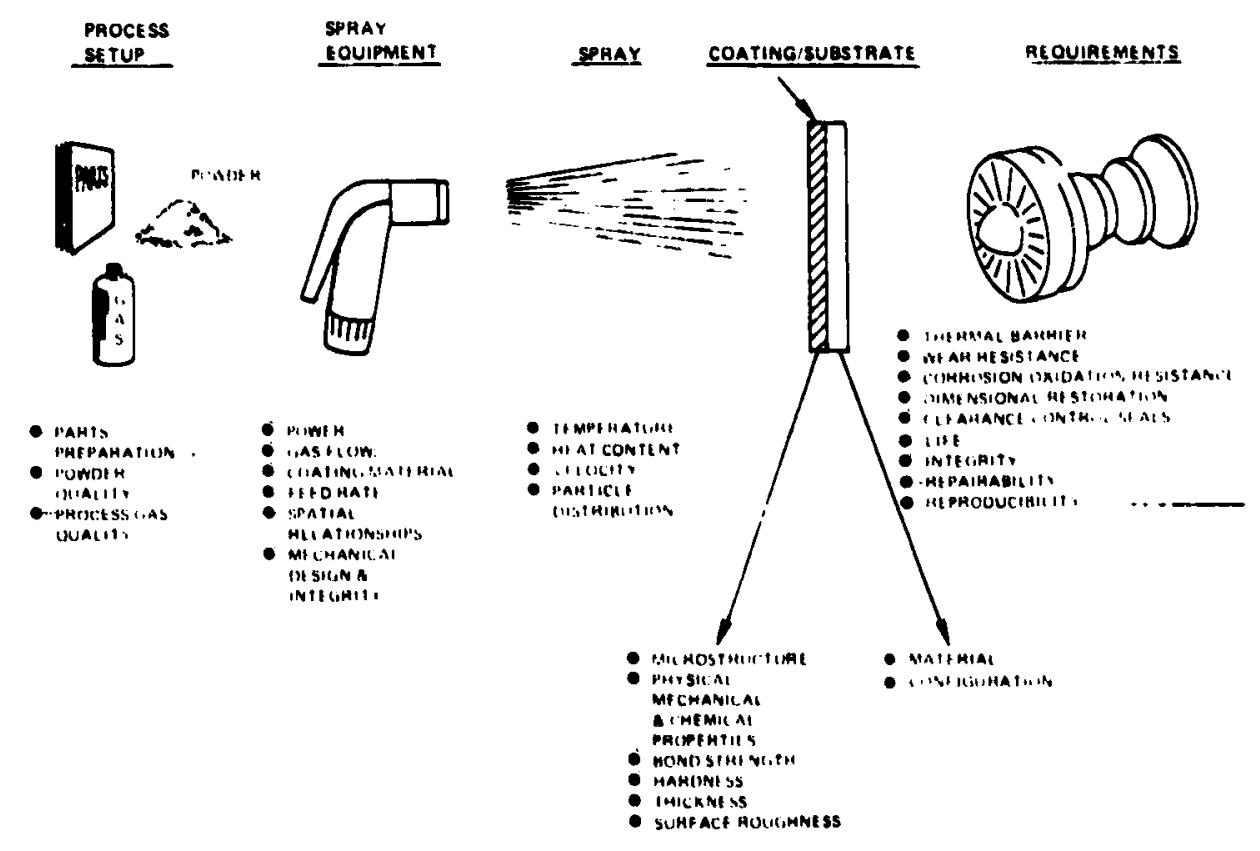

Figure 5.7 Elements of the Plasmia Spray Process

Stress calculations using a suitable model of the spray process and the coating/substrate system have indicated that residual coating stresses can be reduced with a time temperature controlled process. Analysis has also indicated the desirability of thermal pre-stressing the coating system in a controlled manner to take advantage of the higher ceramic compressive strength and achieve increased coating thermal fatigue life. It has been demonstrated experimentally as part of the UTC research effort, that temperature control of the substrate will affect the thermal stress levels of the coating during the arc plasma spray process. Precau- 
tions must be exercised to prevent overheating and oxidation of the substrate which will reduce coating adhesion. Development of a thermal stress control technique offers potential for significant coating durability improvements. Coating Process Development Tasks 1. 2. and 3 are directed at developing the thermal stress control_techniques.

Thermal fatigue specimens will be constructed to simulate airfoil configurations with provisions to readily install instrumentation. Half cylinder shell specimens will be instrumented with thermocouple and strain gages, coated on the convex side and used to cvaluate the effects of curvature on coating durability. Specimens made from flat plates are used by P\&WA to model vane platforms and evaluate coating durability under thermal cyclic conditions. Thermocouples mounted at the coating interface and the metal plate back surface permit calculation of the heat flux through the coating. Through the use of an analytical model, stresses are calculated based on measured temperatures. These tests are used to screen thermal barrier coatings for platform and airfoil applications.

Task 4 is aimed at developing the coating application techniques. Component size and shape will influence the methods used-to apply the arc plasma spray coating. Large components, such as "FT50 type" high temperature turbine components will present processing problems to which solutions must be sought to control residual stresses and coating quality. Coating thickness control is also necessary to minimize stress concentrations, establish a uniform insulation, and maintain specified aerodynamic contours.

A capacity for measuring coating thickness during the plasma spray process is of particular importance in realizing an automatic system. Currently, coating thickness measurements are obtained by interrupting the spray process and manually taking micrometer readings to determine the thickness of coating deposited and then proceeding incrementally until the required coating thickness has been obtained. Improved methods of thickness measurement would contribute significantly to the reproducibility of coating quality by improving the 'epeatability of conditions under which the coating is deposited, thus eliminating the necessity to interrupt spraying to measure thickness and by improving gradation control for reproducibility to graded coating systems.

Another application technique that requires development is the coating surface finish. Smooth thermal barrier coating gas path surfaces are required for aerodynamic efficiency and minimized convective heat load. Rough surfaces affect skin friction, which causes increased pressure losses and increased heat transfer. Arc plasma sprayed coatings, as currently applied, have adequate smoothness for bumer liners; however, improvements are required for use on turbine airfoils.

Surface roughness of the plasma deposited coating is primarily related to the angle of deposition and the powder particle size. Since most of the plasma spraying performed at Pratt \& Whitney Aircraft is done perpendicular to the part to be coated, the effect of deposition angle is minimal. Powder particle size, however, will generally have a significant effect upon as-deposited coating roughness. Deposition methods currently used in as-deposited NiCrAlY surface roughness of approximately 6 micrometers ( 250 micro-inches). This roughness condition is advantageous for the bond layer of a two-layer thermal barrier coating in order to promote adherence of the subsequent ceramic layers. 
The surface roughness of the ceramic layer is influenced by the starting powder particle size as well as the roughness of the metallic bond layer and the thickness to which the ceramic layer is sprayed. Cenerally, a finer ceramic powder particle size will produce a smoother coating surfaci finish. For this reason, a finer ceramic-powder particle size than $-200 /+325$ mesh would be advantageous.

A typical as-sprayed ceramic surface has a mean variation that exceeds 7.6 micrometers 1.300 micro-inches). To achieve smoothness comparable to metallic overlay coatings (less than 1.9 micrometers ( 75 micro-inches) RMS). the thermal harrier coating surface must be finished with a mechanical or chemical treatment. Several post-coating treatments are available for reducing surface roughness. Possible methods include wire brushing, vapor honing. and glassbead peening.

\subsubsection{Coating Durability Technology}

High temperature and pressure thermal fatigue testing of hot section components will ho conducted to evaluate coating durability. The best themal stress control tedinicules and coating application techniques developed in the process technology task will be demonstrated in component rig tests.

Coating airfoiis and platforms will be instrumented and installed in high temperature and pressure cascade rigs to evaluate and develop coating component durahility. Data obtained from thermal fatigue cascade testing is expected to provide a good base for developing the life prediction system. The instrumented components will provide infomation for durability evaluations and allow design modifications to achieve increased life.

Piggy backed engine tests are planned to demonstrate the themal barrier coating system in the engine environment and identify the problems not exposed during rig or lahoratory tests. Coated burmers, platforms and airfoils must be evaluated to understand the specific problems and fillure modes associated with each component and to permit development of along life design for each component.

\subsubsection{Coating Erosion - Corrosion Technology}

The purpose of the erosion-currosion technology task is to identify and develop the resistance mechanisms of the thermal barrier coating system for increased life when operating with residual fuels. The first subtask is identified to set up the dynamic combustor and characterize the thermal environment prior to conducting the oxidation erosion tests and thru the corrosionerosion tests, subtasks 2 and 3, respectively. Separation of the crosioninformation for developing increased coating resistance.

A thennal barrier coating's primary function is to reduce surface heat flux thereby allowing either reduced cooling air at a constant substrate temperature or reduced substrate temperature at a constant coolant flow. Most components require coatings such as CoCrAly to provide protection from the corrosive turbine environment. Thermal barrier 
coatings must therefore either provide that protection, or be used in.conjunction with an environmental protective coating such as CoCrAly. In addition, the thermal barrier coating must itself resist corrosion if it is to remain adherent and otherwise effective.

P\&WA experience to date has not shown corrosion of themal barrier coatings to be a major problem: however, sulfur cortosion of magnesia stabilized zirconia has been observed along with oxidation of the grading alloy. The Navy (Naval Ship R\&D Center Report 4428 ) has also observed minor attack of zirconia stabilized with magnesia and yttria by sodium sulfate and has identified the requirement for a protective under layer sucth as CoCrAly. These reactions have not compromised the thermal barrier coating integrity or bonding on burner liners; however, to insure success on less complaint components such as airfoils. laboratory tests are required to further define the phenomenon and optimize coating resistance.

The oxidation corrosion resistance of ceramics is generally considered to be excellent: however, high temperature reactions involving fuel inpurities and ingested salt can affect their properties. It is well known that sulfur reacts with magnesiun oxide to form magnesium sulfate in petroleum based fuel combustion. and this reaction forms the basis for mitigating hot corrosion by treating industrial boiler fuels with magnesium-bearing additives.

Calcia is also reported to react with $\mathrm{SO}_{2}$. Both $\mathrm{MgO}$ and $\mathrm{CaO}$ are commonly used as stabilizers for zirconia, and it is anticipated that extended exposure of these materials to gas turbine environments will result in some degree of reaction and an associated undesirable partial destabilization of the circonia coating. Furthermore, the effect $\mathrm{MgSo}_{4}$ and $\mathrm{CaSO}_{4}$ will have on further corrosion of the insulator, the substrate or grading alloy is not known. Although no service problems have arisen, magnesium sulfate has been observed on bumer liner thermal barrier coatings in experimental engines.

Another stabilizer for zirconia is yttria, which is relatively inert with respect to the turbine environment. This property makes yttria a very strong thermal barrier coating composicional candidate.

Laboratory evaluation of the corrosion resistance of thermal barrier systerns will permit comparison of candidate inaterials and selection of a system with a high probability of success on turbine airfoils. Cyclic burner vig testing is proposed which simulates coating temperature distributions and fluctuations representative of the gas turbiris: The combined effect of ceramic/metal corrosion and mechanical interaction will be evaluated. Coating modifications will be incorporated based on the test results to improve coating durability.

Erosion \& Impact Resistance - Good erosion resistance is required for durable thermal barrier coatings since the loss of insulation materia! by this mechanism wili reduce the coating barrier efficiency. Thermal barrier coatings do not suffer from erosion damage in burner liner applications. However, the erosion susceptibility of turbine blades may be more severe since gas velocities are higher and the particle impingement angles are less favorable than in bumer line rs. Laboratory evaluation of the crosion resistance of candi- 
date thermal barriser coating materials is required for selection of the best system. The thermal barrier coatings/aiffoil system will be designed to subject the substrate to minimal corrosion susceptibility in the event of foreign object damage.

\subsection{PHASE III - DESIGN SUPPORT TECHNOLOGY}

The tasks of Phase III are the meusurement of thaterials design properties, and the development of design tasks such as computer analysis programs and development of a coating life prediction system.

\subsubsection{Material Design Properties}

The measurement and correlation of thermal barrier coating mechanical and thermal properties is necessary to support the design effort aimed at achieving a durable turbine system with good performance characteristics. Materials design properties acquisition is planned in the as-processed new material state and in an aged material state. Since this is a requirement to burn residual fusels. the effects of contaminents in the fuel and their influence on materials design properties must be experimentally cvaluated.

\subsubsection{Thermal Properties}

The basic material properties required for the heat transfer analysis are thermal conductivity, heat capacity, and density. Other thermal properties recuired for heat transfer and structural analysis of hot section components are radiative absorptivity and linear expansion.

Thermal Conductivity The themal conductivities of are plasma spray deposits of both ceramic and metallic thermal barrier coating materials are known to vary with temperature level and high temperature aging. In addition, the arc plasma spray process produces materials whose conductivity is significantly lower than that of conventionally procisiod metals and ceramics. Therefore, it is necessary to measure the thermal conductivity of the coating constituents over the temperature and life of intended application.

Heat Capacity - Heat capacity is expected to he less dependent on the couting deposition process than themal conductivity; however, many of the ceramic materials which are candidates for thermal barricr coating constituents are prone to phase de-stabilization with attendant phase transitions occurring with temperature transients. The heat of transformations (when applicable) and heat capacities of the various coating constituents must be cvaluated, particularly in the case of the ceramic materials.

Density -.. Room temperature density measurements combined with thermal expansion properties are adequate to define the density of thermal barrier coated materials. Permanent changes of densities (up to $20 \%$ ) resulting from relaxation of the initial deposits will be assessed Juring the thermal expansion testing.

Thermal Radiative Absorptivity - The optical properties of turbine and burner liner surfaces play an important role in the overall heat transfer when there is direct exposure to 
flame generated thermal radiation. Under certain operating conditions, the radiative heat load may be greater.than the convective heat load. The radiative heat load is a function of temperature, flame luminosity, surface thermal radiative absorptince, and coupling or geometry factor. Coal derived fuels are expected to produce flames with very high luminosity because of the increased particulate content. Accurate knowledge of the spectral normal absorptivity of the proposed coatings over the frequency range of maximum flame radiative power is required.

Thermal Expansion -- The thermal expansion of arc plasma spray (APS) de: osited materials is basically similar to that of conventionally processed materials, but there are several significant differences. APS coatings characteristically have high internal energy which arises from the quenching inherent in the coating process. Depending on the material, there is usually anisotropic non-reversible shrinkage (or expansion) which occurs during the initial equilibration of the coating during engine exposure or thermal expansion testing (or other heat :-atments). In aldition, since the material is quenched from a liquid phase, any phase which is in equilibrium for a given composition from the liquidus to room temperature may be initially present in the coating depending on the kinetics of phase transformation and overall cooling rate. Transition of these metastable phases during the initial equilibration of the coating may have a strong effect on the initial thermal expansion. Currently successful coatings are known to undergo phase changes and non-reversible dimension changes, but to insure the successful application of new materials. this behavior must be understood.

\subsubsection{Mechanical Properties}

Stress anayysis of the coating substrate system is required to achieve a successful design and predict conditions of coating delamination or fracture. Stresses result from mechanical loading, thermal transients, and discontinuities in material properties which are presented in certain multi-phase materials and coating systems. An understanding of these mechanisms is based on the thermal properties, the mechanical environment, and the elastic and strength properties which are central to all stress oriented failure analyses.

Eiastic moduli and strength are strong functions of codting morphology. Porosity and material discontinuities such as cracks resulting from the coating process or phase transformation or thermo-mechanical stresses determine the strength and elastic behavior of the materials. These properties are known to vary with time and temperature and should. be measured after an appropriate heat treatment to bring the structure to equilbrium.

Modulus of Elasticity - The modulus of elasticity will be determined in four-point bend testing of coating specimens representative of the ceramic and the graded ceramic/metallic materials. Ambient temperature and a series of intermediate temperatures up to the maximum estimated operating temperature will be tested.

Modulus of Rupture - The modulus of rupture or bend strength will be measured in fourpoint bending by straining the modulus of elasticity samples until failure. Data will be taken at both ambient and the maximum estimated temperature levels. The modulus of rupture will be calculated and the strair to failure also reported. A linear dependence of modulus of rupture with temperature will be assumed to calculate intermediate temperature stress levels and safe strain limits. 
Mechanical Fatigue Mechanical high cycle fatigue testing of thermal_barricr coated rotating components is required to identify any possible reduction in substrate fatigue strength or changes in resonances which would compromise an engine design. High cycle isothermal fatigue tests will be conducted to establisl coating HFF strength.

\subsubsection{Design Tools Development}

This section discusses-research and development work which will be funded by the United Technologies Corporation.

\subsubsection{Analytical Tools}

Coating stresses and coating interactions with the airfoil configurations and platform interfaces must be evaluated to design structures with minimum stresses. Three dimensional analysis techniques are best suited to evaluate such complex structural or material problems. Three dimensional me thods are not used, however, for routine designs where appropriate assumptions.and judgements cim be made to avoid the higher costs associated with complex computer analysis. Current turbine design programs must be modified to handle multi-material systems and airfoils with thick coatings, i.e., coatings thicker than $0.13 \mathrm{~mm}$ $(0.005$ inch). Both airfoil structural and heat transfer design decks must be modified to meet the requirements of thermal barrier coatings and permit evaluation of coating/structural interactions.

\subsubsection{Life Prediction-System}

The development of a coating life prediciton system is based on the study and correlation of results from a well planned devleopmetn program including related experience. IR\&D work has been directed at obtaining the data necessary to build the prediciton system. Preliminary failure theories have been postulated based on thermal fatigue specimen testing during the past two years. Also, fundamental materials properties programs in the thermal, mechanical and chemical areas have been initiated. However, these materials designs data must be coupled with component rig and engine test results to establish design criteria for the life prediction system. Continued development work is necessary to verify, complete orextend life analysis concepts.

\subsection{PHASE IV - ENGINE PROGRAMS}

The demonstration of the thermal barrier coating in a commercial industrial gas turbine will require planning, coordination, and design activities. The use of the FT 4 industrial gas turbine as a test vehicle offers several advantages. Installation of thermal barrier coated components in some of the numerous FT-4 engines currently operating in the industrial environment will provide an excellent source of field data. Another advantage of the FT 4 is that it currently uses convectively cooled turbine components which are riadily adaptable to the thermal barrier coating. Although a redesign effort will be required to accommodate aerodynamics and possible cooling flow changes, the modifications are feasible. The preparation for an engine program will require component design modifications, procurement, fabrication and assembly tasks prior to conducting the thermal barrier coating tests and service evaluation. The engine demonstration is planned to follow the durability technology tasks. It is therefore not fully defined, allowing program flexibility to take advantage of the durability technology developed. 
APPENDIX.A.

\section{COATING PROPERTIES AND FUEL SPECIFICATIONS}

\section{THERMAL BARRIER COATING PROPERTIES}

\section{Radiative Properties}

Figures A-1 and A-2 present the measured normal spectral emittance of yttria stabilized zirconia and commercially pure zirconia, respectively. The emittance in both figures is similar and show very low emissivity $(0.2 \cdots 0.3)$ for short wavelength radiation. Figure A-3 shows the radiation flux from a high temperature source concentrated in the shorter wavelengths (i.e., $<10$ microns), therefore the predicted absorptivity for the selected thermal barrier coatings is $0.2-0.3$ for a new clean rurface absorbing radiation from the flame source.

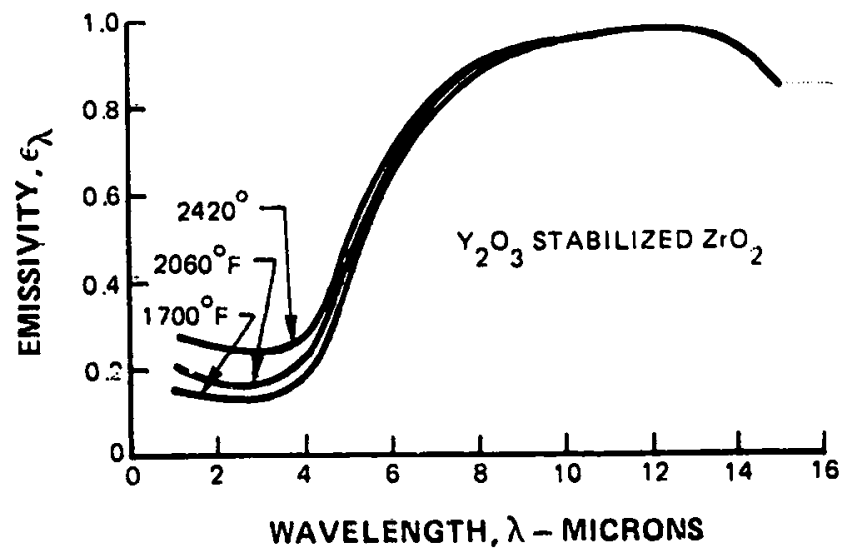

Figure I Measured Normal Spectral Emittance of Ytrria Stabilized Zirconia

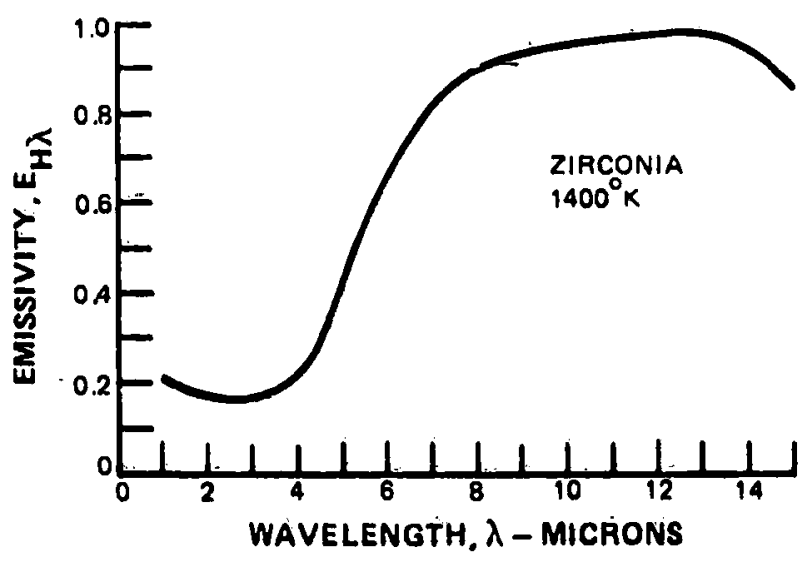

Figure 2 Normal Spectral Eimittance of Commercially Pur̃e Zirconia at $1400 \mathrm{~K}$ 


\section{FUEL SPECIFICATIONS}

The fuel specifications used in the study are listed in Table A-II.

\section{TABLE A-II}

\section{TURBINE FUEL SPECIFICATIONS TO BE USED IN} THERMAL BARRIER SYSTEMS STUDY

\section{Property}

Gravity, ${ }^{\circ} \mathrm{API}, \mathrm{Min}$.

Kin. Visc., cs, $100^{\circ} \mathrm{F}, \mathrm{Min}$.

Kin. Visc. cs, $100^{\circ} \mathrm{F}$. Max.

Kin. Visc., cs, $122^{\circ} \mathrm{F}$, Max.

Flash Point, ${ }^{\circ} \mathrm{F}$, Min.

Dist. Temp., ${ }^{\circ} \mathrm{F}$, Min.

Dist. Temp., ${ }^{\circ} \mathrm{F}$. Max.

Pour Point. ${ }^{\circ} \mathrm{F}$, Max.

Carbon Res. (10\% Bot.), Wt. \%, Max.

Ash, Wt. \%, Max.

Trace Metals, ppm, Max.

Vanadium

Sodium Plus Potassium

Calcium

Lead

Water and Sediment, Vol. \%, Max.

Sulfur, Wt. \%, Max.

Nitrogen, Wt. \%, Max.

Hydrogen, Wt. \%, Max.

Higher Heating Value, Btu/lb

Cost, $\$ 10^{6} \mathrm{Btu}$

*Assume fucl preheating required

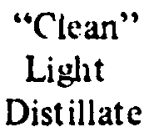

30

2.0

4.3

100

540

640

20

0.35

0.01

0.5

0.5

0.5

0.5

0.05

0.5

0.06

13

19,350

2.60
"Typical" Residual

Fuel

18.5

5.8

6.38

150

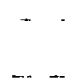

0.03

200

10

10

5

1.0

1.0

0.20

11

18.500

2.15 